University of Chicago Law School

Chicago Unbound

Journal Articles

Faculty Scholarship

1997

\title{
The Political Economy of the Bankruptcy Reform Act of 1978
}

Eric A. Posner

Follow this and additional works at: https://chicagounbound.uchicago.edu/journal_articles

Part of the Law Commons

\section{Recommended Citation}

Eric Posner, "The Political Economy of the Bankruptcy Reform Act of 1978," 96 Michigan Law Review 47 (1997).

This Article is brought to you for free and open access by the Faculty Scholarship at Chicago Unbound. It has been accepted for inclusion in Journal Articles by an authorized administrator of Chicago Unbound. For more information, please contact unbound@law.uchicago.edu. 


\title{
THE POLITICAL ECONOMY OF THE BANKRUPTCY REFORM ACT OF 1978
}

\author{
Eric A. Posner*
}

\section{INTRODUCTION}

Why do we have a bankruptcy law? The conventional story is that bankruptcy law reflects two requirements of a modern commercial economy: a method for the orderly payment of debts owed to multiple creditors and a means to ensure that individual debtors retain sufficient assets and rights to maintain a dignified or at least nonpenurious existence. No doubt this story contains elements of the truth, but it also has many limitations. The story does not explain many significant attributes of the Bankruptcy Code, including the administrative structure it establishes, its reliance on a mixture of federal- and state-determined rights, and its balancing of interests between creditors and debtors.

When commentators try to explain these aspects of the Bankruptcy Code, they generally describe them as the result of conflicts between debtor interests, on the one hand, and creditor interests, on the other. The outcome is explained as just a compromise reflecting the relative political power of each group. On reflection, however, this explanation is not satisfactory. It does not take account of the following factors: (1) different kinds of creditors have different, and often conflicting, interests; (2) other actors have a strong interest in the Bankruptcy Code, including lawyers, judges, agency officials, managers and shareholders of corporations, and politicians; and, perhaps most significantly, (3) debtors, considered as the class of people who are potential beneficiaries of bankruptcy law, do not compose an organized and politically influential group. A satisfactory explanation of the Bankruptcy Code must take into account the interests of all relevant parties and the extent of their political power.

* Assistant Professor of Law, University of Pennsylvania. B.A. 1988, Yale; J.D. 1991, Harvard. - Ed. Thanks to Barry Adler, Jack Ayer, Douglas Baird, Lucian Bebchuk, Frank Easterbrook, Bob Feidler, Rich Hynes, Ed Kitch, Ken Klee, Kevin Kordana, Richard Levin, Harvey Miller, Randy Picker, Ed Rock, David Skeel, Stephen Williams, and participants at a talk at the University of Virginia Law School and at a conference sponsored by the Institute for Law and Economics, University of Pennsylvania. Special thanks to Alan Schwartz and Ron Trost, who prepared formal comments for the talk at Penn, and to Andrew Gallo, for valuable research assistance. 
An understanding of the political influences on the origin of the Bankruptcy Code is of considerable importance at the present time. In 1994 Congress created a National Bankruptcy Review Commission for the purpose of evaluating the bankruptcy system and proposing amendments. ${ }^{1}$ The Commission has held hearings, has voted on a variety of proposals, and is expected to issue a report in October, 1997.2 One question that has not received much attention concerns the extent to which political realities constrain the Commission's behavior and the extent to which they will affect Congress's reception of its report. One way to approach this question is to look back at the political background of the Bankruptcy Reform Act of 1978, develop a political theory of its origin, and use this theory to shed light on the political determinants of the bankruptcy amendment process.

These are the goals of this article. In particular, this article analyzes the legislative history of the Bankruptcy Reform Act of $1978^{3}$ and related materials, in the hope of describing the influence of interest groups on the final statute. It has, of course, long been assumed that certain narrow provisions of the 1978 Act reflect the influence of interest groups - for example, the section that gives special protection to security and lease interests in aircraft. ${ }^{4}$ This article goes farther and argues that fundamental elements of the 1978 Act reflect political compromises among competing interest groups. In particular, I claim (1) that the allocation of powers to bankruptcy judges and trustees resulted from efforts by Congress to increase its patronage opportunities, (2) that the provisions on exemptions resulted from a conflict between federal and state officials over the power to make transfers to local interest groups, and (3) that the provisions on business reorganization resulted from efforts by managers' lawyers and large creditors to maximize their influence on the reorganization of distressed firms, at the expense of other interests, such as equity and small debt. I make similar claims about the provisions on reaffirmation, student loans, and the fraud exception to the right to discharge.

1. See Bankruptcy Reform Act of 1994, Pub. L. No. 103-394, § 603, 108 Stat. 4106, 4147 (codified at 11 U.S.C. cmt. preceding $\$ 101$ (1994)).

2. See National Bankruptcy Reform Commn., NBRC Fact Sheet (last modified Aug. 12, 1997) <http://www.nbrc.gov/facts.html>.

3. Pub. L. No. 95-598, 92 Stat. 2549 (codified as amended at 11 U.S.C. (1994), in scattered sections of 28 U.S.C. (1994), and in scattered sections of other titles of U.S.C. (1994)). The law had no official title and has been called the Bankruptcy Act, the Bankruptcy Reform Act, and the Bankruptcy Code; however, for precision, I use the last term to refer to the bankruptcy law as it currently exists - that is, as amended since the 1978 Act.

4. See 11 U.S.C. $\S 1110$ (1994). 
These conclusions grow from the application of ideas from public choice theory to the legislative history of the Bankruptcy Code. The use of this methodology represents a departure from most bankruptcy scholarship, which is normative, doctrinal, or empirical. This article, in contrast, analyzes the political determinants of bankruptcy law: its contribution is its description of the ways in which the political process resulted in a particular kind of bankruptcy system. 5

Because of the length of the article, a brief overview will be helpful to the reader. The argument begins in Part I with a general discussion of the features that are generally believed to characterize a socially desirable bankruptcy law. This discussion provides a baseline for identifying distortions caused by the influence of interest groups. To clarify the nature of these political interests, Part II contains a stylized cast of characters, categorized into debtors, creditors, elected and unelected federal authorities, state authorities, and lawyers, and analyzes their interests in bankruptcy reform. After some methodological notes in Part III, Part IV describes the legal and political background of the Code. It describes the 1898 Act, as amended, that prevailed prior to the enactment of the Bankruptcy Reform Act in 1978; it discusses the sources of dissatisfaction with the 1898 Act; and it summarizes the legislative history of the 1978 Act.

Next come the arguments about the influence of interest groups on the final statute. Part V analyzes the administrative structure created by the 1978 Act. Part VI analyzes the exemption rules. Part VII analyzes the provisions relating to corporate reorganization. Part VIII analyzes three less significant issues that nonetheless generated a great deal of controversy: the dischargeability of educational loans, the reaffirmation of debts, and the fraud exception to discharge. The conclusion, Part IX, draws out the implications of the arguments for bankruptcy reform and discusses some of

5. Such a project is long overdue for so significant a piece of legislation as the Bankruptcy Code. Theoretically informed analyses of legislative history or the law are common for other areas of the law. See, e.g., Mark Barenberg, The Political Economy of the Wagner Act: Power, Symbol, and Workplace Cooperation, 106 HaRv. L. REv. 1379 (1993) (labor law); Mark J. Roe, A Political Theory of American Corporate Finance, 91 Colum. L. Rev. 10 (1991) (laws governing corporate finance); Roberta Romano, The Political Economy of Takeover Statutes, 73 VA. L. REv. 111 (1987) (state takeover statutes); Alan Schwartz \& Robert E. Scott, The Political Economy of Private Legislatures, 143 U. PA. L. REV. 595 (1995) (private legislatures). The only sustained analysis of bankruptcy law from this perspective focuses on post-1978 law. See Susan Block-Lieb, Congress's Temptation to Defect: A Political and Economic Theory of Legislative Resolutions of Financial Common Pool Problems (1997) (unpublished manuscript, on file with the author). 
the proposals currently before the National Bankruptcy Review Commission.

\section{Normative Theories of Bankruptcy LAW}

In public choice studies it is standard to describe the optimal version of the law in question and use interest group theory to explain the observed deviations. This approach raises difficulties because the optimal version of a particular law may be controversial. Bankruptcy law is no exception. Nevertheless, a few comments on the academic debate concerning optimal bankruptcy law may provide a useful, if rough, baseline for the political analysis.

\section{A. Procedures for the Satisfaction of Multiple Claims}

The optimal bankruptcy law solves a collective action problem that arises when a debtor defaults on loans from several creditors. Default frequently occurs when a debtor borrows from multiple creditors and has too few assets to pay back all of them. In the absence of a bankruptcy system, the creditors would have an incentive to race to the courthouse and obtain a judgment before the other creditors realized that the debtor is insolvent. The reason is that under state law the first creditor to obtain a judgment against a debtor has a better chance to seize the debtor's assets than later creditors do. The race to the courthouse creates several costs, including the cost of monitoring the debtor closely in order to be the first to detect an impending default and the loss of the going-concern or relationship-specific value of assets that occurs when solvent debtors with temporary cash-flow problems are driven into insolvency because creditors prefer seizing assets immediately to maximizing the value of all the debtor's assets. Bankruptcy law reduces these costs by providing for an orderly collection procedure, including (1) an automatic stay that prevents creditors from pressing a claim unless it would be destroyed by the delay, and (2) a distribution system that for the most part respects prebankruptcy entitlements. ${ }^{6}$

In theory, the collective action problem could be mitigated through bargaining. Ex ante, creditors can protect themselves with security interests, debt covenants, and other contractual provisions; in the absence of the Bankruptcy Code's restrictions on waivers

6. For discussions of these familiar points, see Douglas G. Baird, A World Without Bankruptcy, LAw \& ConTEMP. PRoBs., Spring 1987, at 173; Thomas H. Jackson, Bankruptcy, NonBankruptcy Entitlements, and the Creditors' Bargain, 91 YALE L.J. 857 (1982). 
they could contractually provide for a post-insolvency division of assets. ${ }^{7}$ Because the rules designed to ensure an orderly collection procedure also affect such bargaining, and the influence of rules on bargaining can be analyzed only with great difficulty, the optimal design of the collection procedure in bankruptcy remains poorly understood.

\section{B. Discharge}

The bankruptcy policy of discharge for consumer debtors does not have as clear an explanation. The puzzle is that debtors, like creditors, want to minimize the cost of credit. The right to discharge, however, increases the cost of credit, because it prevents creditors from collecting some of their debts, and they must pass on their costs to debtors in the form of higher interest rates. Although debtors who face unanticipated costs ex post should be delighted with the chance of discharging their debts, the policy injures the interests of debtors as a class. Another way of putting this is that people who already have a lot of debt may support discharge; but the vast majority of people, who, whether or not they already have debt, expect to continue taking on debt into the future, should object to the (nonwaivable) right to discharge. ${ }^{8}$

There are two possible solutions to this puzzle. 9 The first assumes that most people see poverty as an evil and are willing to pay, through taxes, to see it reduced. The nonwaivable right to discharge supplements the welfare system in two useful ways. First, it discourages debtors from contracting out of the welfare system by using as collateral assets that are necessary to minimal well-being. Welfare laws prohibit the use of welfare payments as collateral; discharge law (along with exemption law) renders valueless "neces-

7. See generally Barry E. Adler, Financial and Political Theories of American Corporate Bankruptcy, 45 Stan. L. Rev. 311 (1993); Lucian Arye Bebchuk, A New Approach to Corporate Reorganization, 101 HARv. L. REv. 775 (1988); Randal C. Picker, Voluntary Petitions and the Creditors' Bargain, 61 U. CIN. L. Rev. 519 (1992); Robert K. Rasmussen, Debtor's 'Choice: A Menu Approach to Corporate Bankruptcy, 71 Texas L. Rev. 51 (1992); Alan Schwartz, Contracting About Bankruptcy, 13 J.L. EcoN. \& ORG. 127 (1997); Alan Schwartz, Bankruptcy Workouts and Debt Contracts, 36 J.L. \& ECON. 595 (1993); see also Barry E. Adler, A Theory of Corporate Insolvency, 72 N.Y.U. L. REv. 343 (1997) (arguing that investors might prefer ex ante routine liquidation of financially distressed firms).

8. See Ronald A. Dye, An Economic Analysis of Bankruptcy Statutes, 24 Econ. INoUIRY 417 (1986).

9. Both are discussed in ThOMas H. JACKSON, THE LOGIC AND LIMTTS OF BANKRUPTCY LAw 225-79 (1986) (discussing discharge and fresh-start policies); the first is discussed in Eric A. Posner, Contract Law in the Welfare State: $A$ Defense of the Unconscionability Doctrine, Usury Laws, and Related Limitations on the Freedom to Contract, 24 J. LEGAL STUD. 283, 307-08 (1995). 
sary" assets, however defined, and future income as collateral by barring creditors from collecting from them. Second, the right to discharge discourages high-risk behavior that would otherwise be an unavoidable side effect of welfare. Because the welfare system protects people from some of the downside risk of investments, it encourages people to take on too much risk. The right to discharge, however, forces creditors to raise interest rates, discouraging some debtors from engaging in risky investments whose cost is externalized on the taxpayer.

On another view, discharge is justified because debtors frequently take on more debt than they really want to. They do so because they are misinformed about the law or about their future resources, or because cognitive error prevents them from recognizing the risks that accompany debt. There may be elements of truth in this argument, but no one has shown that these problems are pervasive enough to justify a departure from the norm of freedom of contract, and no one has shown that the nonwaivable right to discharge - rather than waiting periods, mandatory disclosure statements, and similar laws - is the most appropriate response to them.

These arguments raise the issue of the optimal level of government for determining the value and kind of property that should be shielded from creditors by exemption laws. Most welfare law is determined by the states, rather than by the federal government, and one justification is that states have more information about local attitudes toward risk and poverty and a stronger incentive to respect them. This justification suggests that exemption law should be left in the hands of the states. A criticism of local control of welfare, however, is that states externalize the costs of poverty on other states. ${ }^{10}$ This criticism suggests that local control of exemption law may also have social costs because of spillovers. ${ }^{11}$ But the direction of the spillover is unclear. On the one hand, it is well known that some states, especially Texas in the nineteenth century, have chosen generous exemptions laws for the purpose of encouraging immigration. Competition for immigrants could lead to suboptimally generous exemption laws. On the other hand, it is also possible that states would choose suboptimally stingy exemp-

10. For a discussion of these issues, see F.H. Buckley \& Margaret F. Brinig, Welfare Magnets: The Race for the Top (June 28, 1996) (unpublished manuscript, on file with author).

11. Cf. Michael H. Schill, Uniformity or Diversity: Residential Real Estate Finance Law in the 1990s and the Implications of Changing Financial Markets, 64 S. CAL. L. REv. 1261, 1262, 1288-1304 (1991) (discussing real estate exemptions and related laws). 
tion laws in order to drive impoverished debtors to other states. We will return to these issues in Part VI.

\section{Reorganization}

The purpose of reorganization is to preserve the going concern value of firms. A firm that enters bankruptcy and emerges intact but with a new capital structure may satisfy creditors' claims more effectively than a firm that is liquidated. There is controversy, however, over how reorganization should proceed. One question is whether the managers of the debtor should retain control over the debtor, on the theory that they alone possess the necessary expertise, or whether an independent trustee should control the firm during reorganization, on the theory that the managers have perverse incentives. Related questions include how much power different kinds of creditors should have over the plan, the court's role in approving the plan, and the protections given the creditors who vote against a plan. ${ }^{12}$

A more complex issue is whether reorganization law should be concerned solely with maximizing the ex ante value of firms or should serve more general social functions, such as minimizing the dislocation that employees would experience if a firm were liquidated, or spreading risk among various kinds of equity and debt investors. ${ }^{13}$ Either view is theoretically possible, but the first view is more plausible. One problem with the second view is that no one has presented evidence showing that fewer jobs are lost when a firm reorganizes than when a firm is liquidated. In fact, reorganizations often involve the firing of employees, and liquidations often involve the selling off of entire components of a business without resulting in a substantial loss of employment. In addition, one must take account of the decline in the demand for labor outside the firm that results from keeping alive an inefficient firm. Another problem with the second view is that no one has provided a rigorous expla-

12. See, e.g., Bebchuk, supra note 7; Mark J. Roe, Bankruptcy and Debt: A New Model for Corporate Reorganizations, 83 CoLUM. L. REv. 527 (1983). Some commentators argue that bankrupt firms should be auctioned off. See, e.g., Douglas G. Baird, The Uneasy Case for Corporate Reorganizations, 15 J. LEGAL Stud. 127 (1986).

13. For discussions of these issues, see Barry E. Adler, Bankruptcy and Risk Allocation, 77 CORNELI L. Rev. 439 (1992); Douglas G. Baird \& Thomas H. Jackson, Bargaining After the Fall and the Contours of the Absolute Priority Rule, 55 U. Crr. L. REv. 739 (1988); Thomas H. Jackson \& Robert E. Scott, On the Nature of Bankruptcy: An Essay on Bankruptcy Sharing and the Creditors' Bargain, 75 VA. L. Rev. 155 (1989). Compare Elizabeth Warren, Bankruptcy Policy, 54 U. CHI. L. REv. 775 (1987) with Douglas G. Baird, Loss Distribution, Forum Shopping, and Bankruptcy: A Reply to Warren, 54 U. CHI. L. REv. 815 (1987) (debating the basis of business bankruptcy policy). 
nation of how reorganization mitigates dislocation. Such an explanation would show, among other things, that unemployment insurance, job-training programs, and other elements of the welfare system would fail to soften the transition more effectively than reorganization law does.

\section{Administration}

A final issue concerns the administration of the optimal bankruptcy law. Little can be said at a high level of generality about the optimal form of administration, but the important issues can be identified. These issues include: (a) the allocation of powers among the bankruptcy judge and the trustee; (b) the allocation of powers among bankruptcy judges and district judges; (c) appointment and tenure of bankruptcy judges, including the question of which level of government should have the appointment power (state or federal) and which branch of government (executive or judicial); and (d) similar questions with respect to the appointment and tenure of trustees.

\section{Cast of Characters}

\section{A. Debtors}

The first category of players consists of debtors. Among consumer debtors it is useful to distinguish between "continuing debtors" and "overburdened debtors." Overburdened debtors are those debtors that gain more from the one-time transfer of wealth from creditors to debtors that occurs when discharge rules are made more generous than they lose from the higher interest rates that they will have to pay for loans in the future. Continuing debtors are those for whom this is not true. Overburdened debtors seek the expansion of their right to discharge; they also prefer a smooth administrative system if discharge is sufficiently generous. Continuing debtors presumably prefer the law of discharge and exemption that properly balances their desire for low interest rates and their desire for protection if they default on their loans, a balance that may (or may not) best be achieved through private contracting. Overburdened debtors may have a strong incentive to organize, particularly during economic downturns when their financial difficulties are most acute; continuing debtors have little incentive to organize.

It is also important to distinguish actual debtors, whether overburdened or continuing, from those who purport to represent 
them. The National Consumer Law Center, for example, claims to represent consumer debtors, but its members have distinct interests that conflict with the interests of debtors. For example, the members might prefer laws that generate business for themselves even though such laws might injure debtors in general and continuing debtors in particular.

In addition, the managers of corporate debtors have interests that conflict with the interests of the corporations or their shareholders. Managers have an interest in retaining control of the corporation even when new management would increase the value of the corporation.

Debtors as a class are not represented in the legislative history. Individual debtors - whether continuing or overburdened - do not give testimony. Corporate debtors are dumb and must speak through their putative representatives, the managers. Shareholders also do not make an appearance. The main debtor-related witnesses are lawyer groups, such as the National Consumer Law Center, and some individual lawyers who mainly represent debtors.

\section{B. Creditors}

Although creditors as a group have many similar interests, they tend to specialize, and as a result creditors often came into conflict in the legislative history. Banks, represented by the American Bankers Association, issue mostly low-risk debt, both secured and unsecured. Credit unions, represented by the National Credit Union Association, issue low-risk debt that can be collected easily through payroll deductions. Finance companies, represented by the National Consumer Finance Association, issue high-risk debt, often secured by household goods and often collected through wage garnishment.14 The National Association of Credit Management and the National Commercial Finance Conference represent a variety of businesses that extend credit to commercial debtors. Trade creditors are not represented, except in a diluted fashion by general institutions like the Commercial Law League. Involuntary or unsophisticated creditors, such as tort creditors and employees, are not directly represented, except that (some) union members are represented by (some) unions. Different creditors have different amounts of power at the state level and at the federal level. 
Because creditors as a group have an interest in minimizing the cost of credit, they should support low exemptions, preserving prebankruptcy entitlements in bankruptcy, and efficient reorganization schemes. ${ }^{15}$ But each kind of creditor has an interest in raising the costs of other creditors when doing so drives the customers of the latter into the arms of the former. For example, banks and other issuers of low-risk credit may favor exemptions for household goods in order to eliminate finance companies' means for ensuring repayment of their high-risk loans. Credit unions might prefer high priority for employees' wage claims against a bankrupt employer in order to reduce the chance that employees who lose wage claims will default on loans from credit unions. Another conflict arises because some creditors, such as banks, have many long-term loans in their portfolios, while other creditors, like finance companies, have many short-term loans in their portfolios. The first group would care more about the effect of bankruptcy reform on their existing assets than would the latter, which can more easily pass on additional costs to its customers. 16

\section{Elected Federal Officials}

The most important elected federal officials in the legislative history were members of Congress (the various presidents do not appear to have taken much of an interest in bankruptcy policy). Members of Congress played two roles in the legislative history. First, they testified in favor of or against certain provisions, for example, the proposed nondischargeability of educational loans. Second, they voted. Members of Congress had an interest in using the opportunity of bankruptcy reform to effect self-serving structural changes in the government. As we shall see, they had an interest in creating new patronage positions and seizing the power to make patronage appointments from different levels of government (the states and localities) and from different branches of the federal government (the courts), and they had an interest in gaining control over areas of policy traditionally in the hands of the states, such as exemption policy. To be sure, the extent to which Congress could

15. One might argue that creditors should not care about proposed laws that would increase the cost of credit, because loans outstanding at the time of enactment are a small fraction of future loans, and creditors can pass on increased costs to future borrowers. But the lost business at the margin may be substantial, and the evidence indicates that the credit industry has found it worthwhile to try to influence legislation. See Vem Countryman, Bankruptcy and the Individual Debtor - And a Modest Proposal to Return to the Seventeenth Century, 32 CatF. U. L. REv. 809, 821-22 (1983); infra notes 189-90.

16. Other important creditors include insurance companies and leasing organizations. 
seize power from other elements of the government was limited by the independent political power of those elements. In addition, the goals of the House and the Senate did not always converge: the conventional wisdom is that the Senate is more sensitive to the interests of states with small, rural populations.

\section{Unelected Federal Officials}

Unelected federal officials included bankruptcy judges, federal judges, trustees, and agency officials. As we shall see, bankruptcy judges had a strong interest in elevating their status to something like that of the federal judges, and the federal judges had an equally strong interest in resisting this elevation lest it dilute their status. Existing trustees may have feared a weakening of their positions. A few federal agencies also had an interest in the legislation. The most important were the Securities \& Exchange Commission, which under old law had an important role in the reorganization of public corporations, and the Justice Department, which had a role in the nomination of judges.

\section{E. Lawyers}

Different kinds of lawyers had different attitudes toward bankruptcy reform. We distinguish among (a) lawyers who specialized in bankruptcy law and who were represented by the National Bankruptcy Conference, (b) lawyers who specialized in commercial law and were represented by the Commercial Law League, and (c) lawyers generally, who were represented by the American Bar Association. We will also see lawyer groups with a local tilt, such as the Dallas Bar Association and the California Bar Association, and other specialty groups, such as the American College of Trial Lawyers. Lawyers as a class had an interest in ensuring that bankruptcy reform would not diminish their role in bankruptcy proceedings, and we shall see them rally against a proposal to give a government agency the role of counseling consumer debtors. They also had an interest in enhancing the "judicial" - as opposed to the "administrative" - character of bankruptcy, because judicial proceedings require the services of people with legal training. But the interests of creditors' lawyers and debtors' lawyers clashed over the extent to which bankruptcy law should serve the interests of creditors or debtors, and the interests of local organizations and national orga- 
nizations clashed over the extent to which bankruptcy law should be determined by state law or federal law. ${ }^{17}$

\section{F. State and Local Authorities}

Local authorities, including governors and state legislators, resist ceding authority to the federal government. One reason for this resistance is that they cannot make transfers to their supporters if they have no control over the law. Another reason is that some states can enact laws that externalize costs on other states. A third reason is simply that state officials enjoy the prestige that comes with power. Consequently, local officials often resist federal efforts to preempt state law. With respect to bankruptcy law, however, local officials are constrained by Congress' constitutional authority to enact a bankruptcy law. ${ }^{18}$ Because Congress has all the bargaining power, local officials can retain local control only when they can give more to Congress in the form of payoffs than Congress could obtain itself through direct regulation. As we shall see, this is a possible explanation for the outcome of the battle over control of exemption policy.

\section{G. Academics}

Academics should be mentioned, since they testified frequently. It is not clear that they should be categorized as a separate interest group, however, since they appeared usually as lawyers representing various constituencies. Sometimes they simply provided information, such as statistics on bankruptcy filings and the history of bankruptcy law.

\section{Methodological Notes}

To analyze a phenomenon as complicated as the legislative history of the Bankruptcy Code, one must make simplifying methodological assumptions. Ideally, we would like to make some assumptions about how political actors behave, on the basis of which we could make "predictions" about the content of the final law, which could be confirmed or falsified by looking at actual events. In practice, we find that the predictions are rough and the events used to test them are messy. Materials available to the re-

17. The political power of lawyers has been extensively studied. See, e.g., Larry E. Ribstein \& Bruce H. Kobayashi, An Economic Analysis of Uniform State Laws, 25 J. LeoAL STUD. 131, 144 (1996).

18. See U.S. CoNST. art. I, $\S 8$, cl. 4. 
searcher, like legislative history, does not necessarily reveal what happened in back rooms and over lunch. Nonetheless, the materials do allow one to adjudicate among the claims of rival hypotheses.

We assume that agents maximize utility. Creditors, debtors, lawyers, and other citizens seek legislation that transfers wealth to them. Judges and other government officials seek prestige, either for its own sake or for its effect on future income. We adopt the standard public choice view that a relatively small number of people with similar interests and a lot at stake will have more of an incentive to organize into politically effective interest groups, while larger numbers of people will have less of an incentive to form such groups. Interest groups have a disproportionate influence on the outcome of legislation, because politicians depend on their financial support for reelection and because politicians depend on the information supplied by interest groups with respect to legislative proposals. 19

But if interest group influence is disproportionate, it is not complete. Legislators maximize their utility by supporting legislation that increases their chances of reelection, but this does not imply that legislators vote only for legislation supported by the most powerful interest groups. Citizens pay attention to some issues and will vote against politicians who frequently support an interest group at the expense of the public. Politicians may need money from the interest groups, but they also need to be able to make a credible claim to voters that they vote consistently with their constituents' interests. The pressure to pay off an interest group while not alienating voters sometimes results in attempts to disguise transfers to interest groups so they cannot be easily identified as such by the voters. ${ }^{20}$

These assumptions produce several hypotheses at a general level: (1) when the public has little interest in an area of legislation, the legislative outcome will transfer resources from the public to interest groups; (2) when powerful interest groups conflict, the legislative outcome will reflect a compromise between them; (3) House and Senate bills will differ according to the influence of different interest groups in the jurisdictions from which members ob-

19. The latter point, sometimes overlooked, explains why even public-spirited legislators are influenced disproportionately by interest groups. For a discussion, see MALCOLM E. JEWeli \& Samuel C. Patterson, The Legislative Process in the United States 195-202 (4th ed. 1986).

20. A survey of this literature can be found in William C. Mitchell \& Michael C. Munger, Economic Models of Interest Groups: An Introductory Survey, 35 AM. J. PoL. ScI. 512 (1991). 
tain their political power; (4) interest groups will seek the placement of legislative power in the level of government in a federal system in which they have the most influence; and (5) as noted above, legislators will disguise transfers when the transfers would otherwise injure the public in a visible way. These hypotheses will guide the discussion below, and will be refined in light of the evidence.

For the most part, the analysis will ignore institutional issues, such as the committee structure in Congress. Although committees are important, ${ }^{21}$ their influence on legislation is not well understood, and the likely gain from examining their role in bankruptcy reform does not justify the increase in the complexity and length of the discussion that would be necessary.

Public-choice analysis frequently ignores ideology, arguing that interest groups seek to acquire wealth rather than vindicate ideological commitments, and members of the public, whether or not ideologically motivated, rarely have the resources or inclination to oppose the efforts of the interest groups. The assumption is useful in some contexts, but it is clearly not always true.22 For example, as Mark Roe shows, the ideology of populism - characterized by a suspicion of concentrated economic and political power - accounts at least partly for the laws that fragment ownership of public corporations. ${ }^{23}$ If populism has influenced corporate law, it seems likely that it also has influenced bankruptcy law.

Ideology, however, played only a minor role in the legislative history of the 1978 Bankruptcy Act. As one would expect, creditors invoked the traditions of laissez faire in this country, and certain debtor and lawyer groups invoked the tradition of providing protection to the poor. But everyone seems to have acknowledged both that credit plays an important role in the economy and should not be overly restricted, and that bankruptcy law serves as a safety net. Much of the debate was about the proper tradeoff: a technical decision made against an unquestioned ideology of welfare-state capitalism. Populist arguments did not appear in the legislative history, though no doubt they played an indirect role through their influ-

21. See, e.g., Heinz Eulau \& Vera McCluggage, Standing Committees in Legislatures, in HANDBOOK OF LEGISLATTVE RESEARCH 395 (Gerhard Loewenberg et al. eds., 1985).

22. Ideological arguments have made a comeback recently. See, e.g., Kerrt T. Poole \& Howard Rosenthal, CONGRESS: A POLITICAL-ECONOMIC HISTORY OF ROLL CALL VOT. INO (1997).

23. See Mark J. Roe, Strong Managers, Weak Owners: The Political Roots of AMERICAN CORPORATE FINANCE (1994); Roe, supra note 5. 
ence on the development of prior legislation. ${ }^{24}$ There were a few desultory appeals to states' rights. It is possible that populism, states' rights, and other ideologies, such as New Deal liberalism, played a powerful role in shaping perceptions, even if they were not clearly expressed in the debates; we consider this possibility below.

\section{LEgAL BACKGROUND OF THE 1978 ACT}

\section{A. The 1898 Act as Amended}

On the eve of the passage of the 1978 Act bankruptcy law was a complicated and arcane field. The complexity was due to many factors. The 1898 Act was itself complicated and vague, and it reflected needs produced by economic and social conditions, including a severe depression, that no longer existed in the second half of the twentieth century. Moreover, Congress had amended the 1898 Act many times, and courts had interpreted the 1898 Act and its amendments in an aggressive way, resulting in a law of bankruptcy that often bore little relation to the statutory text. By the 1960s observers were expressing a great deal of dissatisfaction with the bankruptcy system. The following sections describe the old law and the criticisms most frequently raised against it.

\section{Administrative Structure}

The two main players under the old bankruptcy law were the bankruptcy judge and the trustee. The bankruptcy judge - prior to 1973 officially known as the "referee" and sometimes unofficially so called up until $1978^{25}$ - decided the disputes that arose in connection with bankruptcy cases. The referee system was controlled by the Judicial Conference of the United States and administered by the Administrative Office of the United States Courts. ${ }^{26}$ The bankruptcy judge was appointed by panels of district judges for six-year terms. Originally, the bankruptcy judge had been considered to be

24. See David A. Skeel, Jr., Markets, Courts, and the Brave New World of Bankruptcy Theory, 1993 Wrs. L. REv. 465, 497-99. Skeel points to populist infiuence on the bankruptcy legislation of the 1930s, which transferred power from managers and lawyers to the SEC. Although Skeel argues that populism continues to be a powerful force, the 1978 Act reversed the effects of the earlier legislation.

25. Federal judges continued to call bankruptcy judges "referees" up until 1978, see, e.g., Report of the Proceedings of the Judicial Conference of the UNTTEd States, SePTEMBER 23-24, 1976, at 47-52 (1976), even though they had submitted to the pressure for the change in 1973, see Bankruptcy Rule 901(7) (1973). The significance of this mildly insulting practice will appear subsequently.

26. See Commission to Study Bankruptcy Laws, 1968: Hearings on S.J. Res. 100 Before the Subcomm. on Bankruptcy of the Senate Comm. on the Judiciary, 90th Cong. 53 (1968) [hereinafter 1968 Senate Hearings] (statement of Judge Edward Weinfeld). 
a kind of clerk or "adjunct" of the district court. The district court had jurisdiction over the bankruptcy case, and although it delegated most of the decisionmaking functions to the bankruptcy judge, appeal from the bankruptcy judge's order was to the district court. In practice, the bankruptcy judge had a great deal of power over the day-to-day operation of the bankruptcy proceeding. The district courts would rarely conduct bankruptcy hearings themselves. The bankruptcy judge made routine decisions regarding the property in the bankruptcy estate (summary jurisdiction) and made decisions regarding property in the possession of third parties when all consented (plenary jurisdiction). ${ }^{27}$ Some commentators argued that the bankruptcy judges did not have'sufficient jurisdictional and remedial powers to decide cases in an expeditious way - they would have to refer issues outside their power to the supervising district court - and that bankruptcy judges' subordinate status weakened their authority with litigants.

The trustee was a private individual, usually a lawyer, who would represent and administer the debtor's estate. When, as frequently happened, the creditors did not elect the trustee, the trustee would be appointed by the bankruptcy judge. The trustee performed many of the functions associated with the trustee today, including those of rejecting executory contracts, operating the debtor's business, pursuing people against whom the debtor had a claim, and arguing the estate's case before the court. However, the pre-1978 bankruptcy judge often engaged in activities within the domain of the post-1978 trustee. The bankruptcy judge would, along with the trustee, attend the first creditor's meetings. As a result, the judge would hear evidence that would not be admissible at trial. The bankruptcy judge and the trustee would have frequent ex parte contact. Sometimes a bankruptcy judge would persuade a trustee to pursue a particular course of action, such as going after property, then rule on the trustee's behavior at a later hearing. Sometimes, a bankruptcy judge would actually negotiate contracts with interested parties - such as between union and management - and give business advice to a debtor in possession. The close contact between the bankruptcy judge and the trustee raised concerns that bankruptcy judges biased their decisions in favor of trustees. ${ }^{28}$

27. See H.R. REP. No. 95-595, at 89 (1977).

28. See id. at 89-91; Richard B. Levin \& Kenneth N. Klee, The Original Intent of the United States Trustee System, NoRTON BANKR. L. ADVISER, Jan. 1993, at 2, 2-3. 


\section{Exemptions}

The 1898 Act incorporated state exemptions by reference. 29 State exemptions were rules that prevented creditors in state actions from collecting debts from debtors by seizing and selling off the exempt assets. These laws exhibited striking diversity in their generosity and in the kind of property protected. The Maryland statute in 1960 , for example, provided for a $\$ 100$ exemption in real property, $\$ 100$ in wages, insurance proceeds, and various other streams of income, and all wearing apparel, books, and tools of the trade. The Texas statute provided an exemption for a rural homestead of 200 acres of unlimited value or an urban residential and business homestead worth up to $\$ 5,000$ exclusive of improvements, all furniture, wearing apparel, a large quantity of livestock, and similar items. According to one study, the average exemption claim in Maryland was $\$ 188$ and in Florida was $\$ 7,427$, with a national average of $\$ 943$. The exemption laws differed in a variety of other ways. Many exemption statutes were archaic, singling out bibles, guns, crops, or farm animals. They reflected the rural origins of states that had since become highly urbanized. Some allowed debtors to waive the exemptions in a contract, others did not. Some allowed debtors to avoid liens, others did not. Some exemption laws had been aggressively modified through common law development, others had not. The lack of uniformity among the statutes, the obsolescence of many of them, and the unintelligibility of some of them led commentators to call for the creation of a uniform system of federal exemptions. ${ }^{30}$

\section{Business Reorganization}

On the eve of the 1978 Act, there were three forms of business reorganization - Chapters X, XI, and XII. Chapter XII was specialized and rarely used, so it will not be discussed. Chapters $X$ and $\mathrm{XI}$ emerged in a loose way from two common law forms of reorganization: the equity receivership (Chapter $X$ ) and the composition (Chapter XI). Simplifying greatly, the equity receivership was a process by which the major creditors of a debtor would, often with the consent of the debtor, obtain a foreclosure and purchase its as-

29. See Act of July 1,1898 , ch. $541, \S 6,30$ Stat. 544, 548 (repealed 1978).

30. The statistics and the descriptions of the statutes come from Vern Countryman, For a New Exemption Policy in Bankruptcy, 14 Rutgers L. Rev. 678, 681-84 (1960). See also Comment, Bankruptcy Exemptions: Critique and Suggestions, 68 YALE L.J. 1459, 1465-69 (1959). But see Frank R. Kennedy, Limitation of Exemptions in Bankruptcy, 45 IowA L. REv. 445 (1960) (defending the old system). 
sets using a newly formed corporation of which all creditors received a share (of equity or debt). A court would appoint a receiver, usually chosen by the major creditors, and creditors could enforce their claims through this receiver. In theory, dissenting creditors were protected by the "absolute priority rule," which held that senior creditors must be paid in full before junior creditors receive any value. ${ }^{31}$ In practice, courts circumvented this rule in order to avoid defeating reorganizations. There was generally little judicial review of the process or the plan eventually agreed to, anyway, and, as a result, creditors and commentators frequently accused managers and senior creditors of conspiring to squeeze out intermediate debt and nonmanagement equity. ${ }^{32}$

Compositions occurred when all creditors consented to a reorganization of the debtor's capital structure. The problem with compositions was that if any creditor declined to cooperate, that creditor either had to be paid off or the composition could not occur. Compositions generally involved the reorganization of small, closely held firms, rather than public corporations. ${ }^{33}$

Dissatisfaction with the common law of reorganization resulted in calls for reform and eventually in legislative amendment in the 1930s. Initial proposals were resisted by the bankruptcy bar apparently because (1) its members would lose the benefit of years of experience with the old law, and (2) the proposals would have created a centralized bureaucracy that would take business from the lawyers. ${ }^{34}$ When the dust settled in 1938, Chapters X and XI had been created.

Chapter X, the successor of the equity receivership, created additional procedural protections. A Chapter $X$ petition could be filed either by the creditors or by the debtors. If the judge approved the petition, he or she would appoint a trustee, who was supposed to operate the debtor's business. The trustee and the creditors could propose plans, but they had to meet elaborate requirements for disclosure of information concerning the relationships of the parties. Thanks to some aggressive interpretation by

31. See Northern Pac. Ry. v. Boyd, 228 U.S. 482 (1913).

32. See Report of THE COMMN. ON THE BANKRUPtCY LAwS OF THE UNITED STATES, H.R. DoC. No. 93-137, at 238-39 (1973) (quoting SECURIIIEs \& ExCH. COMMN., REPORT ON THE STUdY AND INVESTIGATION OF THE WORK, ACTIVITIES, PERSONNEL AND FUNCTIONS OF Protective and Reorganization Committees, pt. 8, at 24-26, 29 (1940). See generally John D. Ayer, Rethinking Absolute Priority After Ahlers, 87 MrCr. L. Rev. 963, 968-73 (1989).

33. See Ayer, supra note 32, at 977.

34. See H.R. Doc. No. 93-137, at 239. 
the Supreme Court, the absolute priority rule prevailed. ${ }^{35}$ The judge was required to dismiss Chapter $\mathrm{X}$ petitions if adequate relief existed under Chapter XI. The SEC had the duty to evaluate the plan and in practice had an important role in the proceedings. ${ }^{36}$

Chapter XI, the successor of the composition, was intended to be used by small, closely held firms. It applied to cases in which all the debt is unsecured; the plan could not affect secured debt. The debtor alone had the power to commence proceedings in Chapter $\mathrm{XI}$, and it alone could make a proposal. Judicial approval of the petition was not necessary. Creditors were supposed to be represented by a creditors' committee, but the latter was often dominated by the more powerful creditors. The plan did not have to satisfy the absolute priority rule; it could be confirmed as long as creditors would receive no less under the plan than they would receive from liquidation. The SEC had no role in Chapter XI. ${ }^{37}$

Chapter X and XI proceedings evolved in ways not foreseen by the drafters. Although, as noted, the drafters intended Chapter XI for close corporations and Chapter $\mathrm{X}$ for public corporations, they did not put rules reflecting these intentions in the statute. Debtors of both kinds preferred Chapter XI, and helped along by a controversial Supreme Court case, 38 usually succeeded in reorganizing under Chapter XI, despite the SEC's time-consuming efforts to convert to Chapter X. By the eve of the 1978 Act, Chapter XI had become the dominant form of reorganization.

The benign interpretation of this development is that Chapter XI proved to be more flexible than Chapter X; the skeptical interpretation, as we will see, is that Chapter XI gave certain powerful interests - managers, managers' lawyers, large creditors - advantages during reorganization. One's choice between the two interpretations would probably depend on how one judged the performance of the SEC. The SEC routinely exercised its right to intervene and be heard on Chapter X matters, participated in meetings and conferences, challenged the qualifications of trustees, attacked the representation of interests on creditors' committees, scrutinized the trustee's administration of the estate, challenged attempts to sell the debtor's property, opposed plans of reorganization that did not adhere to the absolute priority rule, and criticized

35. See Consolidated Rock Prods. Co. v. Du Bois, 312 U.S. 510 (1941); Case v. Los Angeles Lumber Prod. Co., 308 U.S. 106 (1939). For details, see Ayer, supra note 32, at 974-78.

36. See H.R. Doc. No. 93-137, at 240-46.

37. See id.

38. See General Stores Corp. v. Shlensky, 350 U.S. 462 (1956). 
compensation arrangements. ${ }^{39}$ These interventions were time consuming, and they were considered a nuisance by those who sought to push through a reorganization plan. But they may also have protected bondholders and equityholders who did not have a large enough stake to participate in the reorganization. The main disadvantage of Chapter XI - that debtors could not modify the rights of secured creditors - was overcome through common law development. A stay would prevent secured creditors from repossessing collateral until the debtor had negotiated a plan with the unsecured creditors, after which the debtor could pay off the secured creditor. The debtor did not have to compensate the secured creditor for the lost opportunity to use the collateral and so had leverage with which to extract concessions from the secured creditor.

There were other problems with Chapters $\mathrm{X}$ and XI, including most prominently the lengthy litigation that was necessary to resolve the question of which chapter was appropriate. After a debtor filed under Chapter XI, the SEC would sometimes raise this question by moving for conversion to Chapter $\mathrm{X}$. Determining which chapter applied was difficult because of the vague "as needed" test created by the Supreme Court. ${ }^{40}$ This benefited the debtor and its management, because they could use the threat of delay and the consequent diminution in the value of assets that could satisfy the creditors' claims to obtain concessions from the creditors. Dissatisfaction with the complexity and manipulability of reorganization law led to calls for reform.

\section{Miscellaneous}

Under the "miscellaneous" category we gather several issues that were not as important as administrative structure, exemption policy, and reorganization but that nonetheless received a great deal of attention during the legislative history of the 1978 Act. The first issue concerned whether debtors could too easily discharge educational loans, in effect converting the federal loan programs into tuition subsidies. The second issue concerned the practice of reaffirmation. Debtors frequently promised to pay prebankruptcy debts in return for postbankruptcy credit from the same creditor.

39. See Michael E. Hooton, The Role of the Securities and Exchange Commission Under Chapter X, Chapter XI and Proposed Amendments to the Bankruptcy Act, 18 B.C. INDUs. \& COM. L. REv. 427 (1977).

40. See Shlensky, 350 U.S. at 466. Shlensky rejected the view that Chapter XI is unavailable to large public corporations, holding instead that the propriety of Chapter XI depends on the "needs" of the debtor. The choice between chapters thus always would be a fact-sensitive inquiry. 
Commentators argued that this practice undermined bankruptcy's fresh-start goal. The third issue was whether shady creditors manipulated the fraud exception to discharge - under which discharge was denied if the debtor had made a fraudulent statement to creditors - with the result that many debtors could not obtain the fresh start they deserved. The argument was that creditors would have debtors fill out confusing forms with the intention of causing debtors to fail to list all their assets and liabilities. This would constitute fraud, resulting in a denial of discharge.

\section{B. Legislative History of the 1978 Act}

The legislative history of the Bankruptcy Reform Act is complex.41 It consists of thousands of pages of hearings, reports, and debates spanning a decade. To simplify the analysis, we divide the legislative history into three stages. The first stage extends from the enactment of the law creating a bankruptcy commission in 1968 to the commission's release of a report and proposed bill in 1973. The second stage extends from the House and Senate hearings on the commission's bill and on an alternative proposed by a group of bankruptcy judges, mainly in 1975 and 1976, to the passage of House Bill 8200 and Senate Bill 2266 in 1978. The third stage covers the resolution of the conflicts between House Bill 8200 and Senate Bill 2266, leading to enactment of the Bankruptcy Reform Act in November, 1978. A brief description of these events sets the stage for the analysis and foreshadows many of its themes.

\section{Stage 1}

Growing dissatisfaction with the bankruptcy laws in the 1960s persuaded first a subcommittee of the Senate Judiciary Committee and then the full Congress to create a commission to evaluate the bankruptcy laws. The original Senate bill provided that the commission would consist of representatives from the House and Senate, three bankruptcy judges, and three businessmen. ${ }^{42}$ Apparently in response to objections from the federal judiciary to the presence of bankruptcy judges and the absence of Article III judges, ${ }^{43}$ the House version of the bill provided for three presidential appointees,

41. For a detailed synopsis of the legislative history, see Kenneth N. Klee, Legislative History of the New Bankruptcy Code, 54 AM. BANKR. L.J. 275 (1980). See also Congress Approves New Bankruptcy System, 34 CoNG. Q. Almanac 179 (1978). This section relies on these articles, as well as on the original statutory sources.

42. See S.J. Res. 100, 90th Cong., \$ 2(a) (1968).

43. See 1968 Senate Hearings, supra note 26 , at 53-55, $63-65$ (statement and testimony of Judge Edward Weinfeld). 
two representatives from the House, two representatives from the Senate, and two appointees of the Chief Justice of the Supreme Court. This version passed the full Congress in 1968.44

The Commission on the Bankruptcy Laws of the United States was formed in 1971 and met over the next two years. In 1973 the Commission issued a report criticizing the existing bankruptcy laws and proposing a legislative replacement known as the Commission's Bill, or CB. 45 The Commission listed the following complaints about the bankruptcy laws:

1. The rapid increase of bankruptcies from 10,196 in 1946 to 208,329 in 1967, and especially of consumer bankruptcies. ${ }^{46}$

2. Administrative waste. For example, in $1972 \$ 6.7$ million of the $\$ 17$ million spent on the operation of bankruptcy courts was spent on no-asset cases. ${ }^{47}$

3. Insufficiently generous fresh start for debtors, and inadequate incentives for creditors to collect in bankruptcy. ${ }^{48}$

4. Lack of uniformity in the treatment of debtors. ${ }^{49}$

5. Abusive or negligent practices by bankruptcy judges, trustees, and bankruptcy lawyers. ${ }^{50}$

The CB contained many modifications of the bankruptcy system, but three stood out. First, it provided for a sharper distinction between bankruptcy judges and trustees, elevating the status of the bankruptcy judges and placing the trustees in a new, centralized bankruptcy agency in the executive branch. ${ }^{51}$ Second, it provided for a system of uniform federal exemptions. ${ }^{52}$ Third, its reorganiza-

44. The Commission was created by the Law of July 24, 1970, Pub. L. No. 91-354, 84 Stat. 468 (eliminated 1973); for the hearings that led to this law, see Bankruptcy: Hearings on S.J. Res. 88, H.R. 6665, \& H.R. 12250 Before Subcomm. No. 4 of the House Comm. on the Judiciary, 91st Cong. (1969); 1968 Senate Hearings, supra note 26. The Commission and other participants were influenced by STANLEy ET AL, BANKRUPTCY: Problem, Process, Re. FORM (1971).

45. The CB was drafted by Frank Kennedy and his staff on the Commission. See Frank R. KENNEDY, ThE ORIGINS AND GROWTH OF BANKRUPTCY AND REORGANIZATION LAWS IN the 20th Century: An Oral History Perspective $49-51$ (1994).

46. See H.R. Doc. No. 93-137, at 2 (1973).

47. See id. at 3 . It should be noted that this statistic may not actually indicate waste but just that a large number of cases were no-asset cases.

48. See id. at $3-4$.

49. See id. at 4.

50. See id.

51. See id. at 6-8.

52. See id. at 11. 
tion provisions consolidated Chapters $\mathrm{X}, \mathrm{XI}$, and $\mathrm{XII}$ and modified the procedural and substantive rules of confirmation..$^{53}$

Infuriated by their exclusion from the Commission and suspicious of its capacity to produce an adequate bill, the bankruptcy judges created their own bill, known as the Judges' Bill, or JB. The $\mathrm{CB}$ and the JB had many similarities but several important differences. ${ }^{54}$ The bankruptcy judge under the JB was to have more power and status than the bankruptcy judge under the $C B$, and the JB did not provide for a bankruptcy agency. The JB provided for minimum, rather than uniform, federal exemptions. Although both bills had special provisions for publicly held corporations, the JB, unlike the $\mathrm{CB}$, would have maintained separate tracks for close corporations and public corporations.

\section{Stage 2}

Representatives Don Edwards and Charles Wiggins introduced the CB in 1973, but little was accomplished that year. In 1974 Edwards and Wiggins reintroduced the $\mathrm{CB}$ as House Bill 31 and the JB as House Bill 32 and during 1975 and 1976 held lengthy and detailed hearings on them before the Judiciary Committee's Subcommittee on Civil and Constitutional Rights. 55 These hearings culminated in House Bill 6, which was introduced in 1977. The Subcommittee held meetings on House Bill 6, which resulted in a new version, House Bill 7330, and after further discussions yet another version, House Bill 8200 . The Judiciary Committee amended House Bill 8200 and issued a new version, along with a committee report.56 Meanwhile, the Subcommittee also prepared a report on the constitutionality of the proposed bankruptcy courts. ${ }^{57}$ The House debated and amended House Bill 8200 in October 1977, but because the legislative managers did not approve of this amendment - a similar one had been rejected by the Subcommittee they removed the bill from the calendar. The Subcommittee held

53. See id. at 28. The Commission also made a large number of proposals regarding the mechanics of bankruptcy and the rights of the parties in bankruptcy; it also made proposals regarding railroad reorganizations and wage-eamer plans. See id. at 9-31.

54. The bills are printed and compared in Bankruptcy Act Revision: Hearings on H.R. 31 and H.R. 32 Before the Subcomm. on Civil and Constitutional Rights of the House Comm. on the Judiciary, 94th Cong. app. (1975-1976) [hereinafter 1975-76 House Hearings].

55. See 1975-76 House Hearings.

56. See H.R. REP. No. 95-595 (1977).

57. See Staff of the Subcomm. ON Civil and Constitutional Rights of the House COMM. ON THE JUDICIARY, 95TH CONG., CONSTITUTIONAI BANKRUPTCY COURTS (COmm. Print No. 3, 1977) [hereinafter 1977 HOUSE SUPP. REPORT]. 
further hearings ${ }^{58}$ and released a new report.59 The House debated House Bill 8200 again in February 1978, reversed the earlier amendment, and passed the bill by a voice vote. 60

The 1977 House Report identified three major problems with the bankruptcy system: (1) impaired adjudication of cases resulting from judges' lack of independence and low status; (2) insufficient relief to consumer debtors; and (3) excessive vagueness. 61 To address these and other problems, House Bill 8200 proposed the following changes to the law.

Administrative structure. House Bill 8200 would have abolished the old referee system. It would have given the new bankruptcy judges full powers of law, equity, and admiralty, including injunctive powers, the power to hold jury trials, contempt power, and jurisdiction over all matters arising in connection with a bankruptcy case, with appeal to the circuit courts. The bill also would have given bankruptcy judges more control over local rulemaking, finances, and so on, so they would not have to defer to district judges, which was considered demeaning. Bankruptcy judges would have become Article III judges, with full tenure and advice-and-consent presidential appointment. ${ }^{62}$ In addition, the bill would have created a system of U.S. Trustees, modeled on the U.S. Attorney system. Trustees would have been autonomous but under the loose supervision of the Department of Justice. They would have had administrative authority over bankruptcy cases. ${ }^{63}$

Exemptions. House Bill 8200 provided for a $\$ 10,000$ exemption for the homestead and $\$ 5,000$ for personal property, among other things, but would have given the debtor the right to choose between the federal and state exemptions - effectively making the federal exemptions a floor. House Bill 8200 would also have given the debtor the right to waive judicial liens on exempt property and nonpurchase money security interests in household-related exempt

58. See Bankruptcy Court Revision: Hearings on H.R. 8200 Before the Subcomm. on Civil and Constitutional Rights of the House Comm on the Judiciary, 95th Cong. (1977) [hereinafter 1977 House Supp. Hearings].

59. See Subcommittee on Civil and Constitutional Rights of the House Comm.

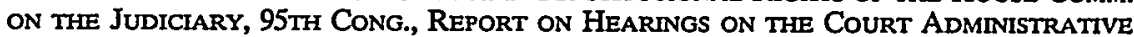
StRUCtuRE For BANKRUPTCY CASEs (Comm. Print No. 13, 1978) [hereinafter 1978 House REPORT].

60. The main members of staff who worked on and drafted the 1978 Act were Kenneth Klee and Richard Levin, on the House side, and Robert Feidler and Harry Dixon, on the Senate side.

61. See H.R. REP. No. 95-595, at 4.

62. See id. at 7.

63. See id. at 88. 
property. ${ }^{64}$ House Bill 8200 would have allowed consumer debtors to redeem collateral. 65

Business reorganizations. House Bill 8200 provided for the consolidation of the old Chapters X and XI, and it chose as the standard for approval of confirmations a substantially more liberal rule than the one that prevailed under Chapter X. The debtor would have had an exclusive 120-day right to propose a plan. The management would presumptively have retained control as the debtor in possession. The $\mathrm{CB}$, in contrast, made the trustee presumptive for large, public corporations. Creditors' committees would have been appointed by the courts. ${ }^{66}$

Miscellaneous. House Bill 8200 retained the discharge exception for false financial statements. Because it was believed that creditors sometimes manipulate debtors, however, if a creditor made this charge but then lost, it had to pay debtors' costs and attorneys' fees. ${ }^{67}$ Over significant objections, ${ }^{68}$ the bill retained the discharge for educational loans. ${ }^{69}$ The bill would have prohibited reaffirmations. ${ }^{70}$

Meanwhile, in the Senate the CB and the JB had been introduced as Senate Bill 236 and Senate Bill 235 in 1975. The Senate Judiciary Committee's Subcommittee on Improvements in Judicial Machinery conducted hearings. ${ }^{71}$ No further activity occurred until 1977, when a new bill, Senate Bill 2266, was proposed and hearings were held. ${ }^{72}$ After the House passed House Bill 8200, the Subcommittee revised Senate Bill 2266 and reported it out to the Judiciary Committee. The Judiciary Committee voted in favor of the new Senate Bill 2266 after amending it, and a report was filed. ${ }^{73}$ After Senate Bill 2266 traveled through several committees, it came before the full Senate, which amended it and passed it by a voice

64. See id. at 126.

65. See id. at 127.

66. See id. at 220-31.

67. See id. at 128-31.

68. See id. at 536-38 (supplemental views of Rep. Ertel).

69. See id. at 132-34.

70. See id. at 365-66.

71. See The Bankruptcy Reform Act: Hearings on S. 235 and S. 236 Before the Subcomm. on Improvements in Judicial Machinery of the Senate Comm. on the Judiciary, 94th Cong. (1975) [hereinafter 1975 Senate Hearings].

72. See Bankruptcy Reform Act of 1978: Hearings on S. 2266 \& H.R. 8200 Before the Subcomm on Improvements in Judicial Machinery of the Senate Comm. on the Judiciary, 95th Cong. (1978) [hereinafter 1977 Senate Hearings] (taking place on Nov. 28-29 and Dec. 1, 1977).

73. See S. REP. No. 95-989. 
vote as an amendment in the nature of a substitute to House Bill 8200. Senate Bill 2266 included the following provisions.

Administrative structure. Senate Bill 2266 would have created less powerful and prestigious bankruptcy judges than House Bill 8200. Bankruptcy judges would have continued as adjuncts of the district courts. Bankruptcy judges would have been appointed by the court of appeals for each circuit, rather than by the President, and would have had a twelve-year term. ${ }^{74}$ Senate Bill 2266 also would not have created a bankruptcy agency in the executive branch, instead keeping the trustee system in the judicial branch. ${ }^{75}$

Exemptions. Senate Bill 2266 followed old law and provided for the incorporation of state exemptions. ${ }^{76}$

Business reorganization. Senate Bill 2266 would have consolidated Chapters X, XI, and XII, but it left a separate track for public corporations. Among other things, it provided for mandatory appointment of a trustee in the case of public corporations. It would have retained the old, strict standard for reorganization of public corporations, while providing for a standard similar to the House's for the reorganization of private corporations.

Miscellaneous. Senate Bill 2266 would have retained the fraud exception to discharge but provided that the debtor is entitled to attorneys' fees and costs if the creditors' claim of fraud is not brought in good faith.77 Student loans would have been nondischargeable for five years after they were due.78 Debtors would have had thirty days to rescind a reaffirmation, but after the expiration of that period reaffirmations would have been enforceable. ${ }^{79}$

\section{Stage 3}

Stage 3 began with an impasse. Congress faced two bills, House Bill 8200 as originally passed by the House and Senate Bill 2266, though the latter was now known as House Bill 8200 as amended by the Senate ("first Senate amendment"). Instead of holding a joint conference, the managers of the legislation conducted negotiations and hammered out a deal. The compromise was reflected in the House's amendment to House Bill 8200, passed in September 1978. In October the Senate passed the House amendment by a voice

74. See id. at 17-18.

75. See id. at 4.

76. See id. at 6.

77. See id.

78. See id. at 79.

79. See id. at 80-81. 
vote after adding several of its own amendments ("second Senate amendment"). The House concurred, also by a voice vote, and the President signed the bill in early November.

The House amendment split the differences between House Bill 8200 and Senate Bill 2266 in several ways. The House prevailed on the transfer of new powers to the bankruptcy judge, but the bankruptcy judge would not be an Article III judge. The Senate prevailed in its efforts to prevent the creation of a bankruptcy agency in the executive branch, but agreed to a limited pilot program to test the idea. The compromise created a uniform system of federal exemptions - for example, a $\$ 7,500$ homestead exemption - but gave the states the right to opt out. It adopted the House's version of reorganization law, with two concessions to the Senate: it included vague provisions designed to create some special protections for cases involving public corporations, and it provided for the automatic appointment of an examiner in such cases, though not of an independent trustee as the Senate had preferred. Reaffirmations were to be permitted, but they had to meet disclosure and related requirements. Numerous other compromises occurred, but we need not detail them. ${ }^{80}$

The provisions of the second Senate amendment are strikingly trivial, but their triviality makes them all the more interesting. The amendment reduced the bankruptcy judges' authority to hire clerks, gave the Judicial Council the power to issue "recommendations" of candidates for the appointment of bankruptcy judges, eliminated the bankruptcy judges' retirement plan, gave the chief judge of a circuit the power to evaluate certain incumbent bankruptcy judges, and even possibly, obscurely, took away the bankruptcy judges' hard-won right to be called "judge" rather than "referee." 81 Because of the lateness of the date, the House passed the second Senate amendment without making further changes.

The second Senate amendment is surprising not only because its provisions were trivial, but also because it seems to have violated the deal made between the House and the Senate. As we shall see, the evidence suggests that Senator DeConcini unilaterally made these changes and told the House that they were non-negotiable. Rep. Edwards was distressed about these changes but could not

80. For a description of the compromises, see 124 CONG. REc. 33,992-4,018 (1978) (statement of Senator DeConcini). Apparently, there were hundreds of points of disagreement, but the conflicts over administrative structure and corporate reorganization generated the most heat. See Telephone Interview with Robert Feidler, Former Counsel to the Senate Judiciary Committee (Jan. 13, 1997) [hereinafter Feidler Interview].

81. See 124 Cong. Rec. 34,144-45 (1978) (statement of the Hon. Don Edwards). 
oppose them at the late date. The House passed the second Senate amendment in early October; the President signed the bill in early November. ${ }^{82}$

\section{Administrative Structure}

Participants in the hearings came into conflict over two major issues of administrative structure. The first issue concerned the power and status of the bankruptcy court. Some participants believed that bankruptcy judges should have broader powers than those they enjoyed under the old law and that they should have greater status; other participants preferred the old law. Because the status of a judge depends in part on the extent of his powers, the questions of power and status were intertwined. The second issue concerned the nature of the administrative apparatus that would control the appointment of trustees. Some participants wanted to create a "bankruptcy agency" in the executive branch; other participants wanted to keep the appointment of trustees in the judicial branch.

Recall that the Senate bill to create a Bankruptcy Commission contemplated that bankruptcy judges would serve on the Commission, but that the final law created slots only for appointments from the executive branch, the Senate, the House, and the federal judiciary. The bankruptcy judges' exclusion from the Commission resulted from the objections of the federal judiciary. During the initial hearings before the Senate in 1968 Judge Weinfeld, speaking for the Judicial Conference of the United States, said:

Here the proposal is that referees be included as well as lawyers, but the fact is that the ultimate judgment with respect to bankruptcy matters is made by judges of the court who review the various actions of referees when petitions for review are presented.

... You must bear in mind that the experts [i.e., referees] have points of view reflecting at times their separate interest - I don't mean this special interest in any invidious sense - but men sometimes become wedded to their particular ideas. It would seem to me that the Commission that we propose [i.e., without referees] would be more concerned with broad-gaged policies .... ${ }^{83}$

82. Apparently, the bill was held up by the Speaker of the House because either he or powerful representatives wanted to prevent the reappointment of a certain bankruptcy judge in Connecticut. The transition provisions provided that all sitting judges at the time of enactment would be automatically reappointed; the Connecticut judge's term expired after the House voted and before the President signed. See Telephone Interview with Kenneth N. Klee, Former Associate Counsel to the House Judiciary Committee (Jan. 29, 1997) [hereinafter Klee Interview]; see also Feidler Interview, supra note 80.

83. See 1968 Senate Hearings, supra note 26, at 63 (testimony of Judge Edward Weinfeld). 
Weinfeld's argument was flimsy. No doubt bankruptcy judges had a "separate interest," but so did everyone else involved in bankruptcy reform. Bankruptcy judges knew more than anyone else about the bankruptcy system, and the oddity of excluding them from the Commission was obvious enough to others - no testifying party outside the federal judiciary seconded Weinfeld's views. ${ }^{84}$ But his views nonetheless prevailed. 85

The most likely reason that the federal judiciary opposed the participation of bankruptcy judges on the Commission is that it feared that bankruptcy judges would use their influence on the Commission to press for a bankruptcy law that would transfer power and status from the federal judiciary to the bankruptcy judges. Bankruptcy judges had long made clear to the federal judiciary their dissatisfaction with their subordinate status, lobbying the federal judges for more autonomy, fancier titles, greater privileges, and the right to participate in judicial policymaking and administration. They felt most keenly their exclusion from the Judicial Conference, the judicial branch's policymaking body. Judge Weinfeld did not admit the motives of the federal judges, of course; but we will see shortly evidence that the federal judiciary's most passionate concern about bankruptcy reform was that the status of federal judges would be diluted by an increase in the power of bankruptcy judges. The House and Senate yielded to the federal judges' objections to the participation of bankruptcy judges on the Commission ${ }^{86}$ probably because they believed that the success of any legislative deal would depend on the judges' cooperation both during legislation and when the statute entered litigation.

The federal judges' victory was short lived. The Commission argued that bankruptcy judges' low status hampered their efforts to adjudicate bankruptcy disputes in a fair and expeditious manner. The solution to this problem was "to enhance the real and apparent judicial independence of bankruptcy judges." 87 One route to en-

84. For a rejoinder from a bankruptcy judge, see 1975-76 House Hearings, supra note 54, at 229-34 (reprinting Conrad K. Cyr, Setting the Record Straight for a Comprehensive Revision of the Bankruptcy Act of 1898, 49 AM. BANKR. L.J. 99, 103-08 (1975)).

85. Justice Burger was entitled to fill his slots with bankruptcy judges, but he resisted the pressure of the bankruptcy judges to do so and appointed two federal district judges. See KENNEDY, supra note 45 , at 47.

86. It is generally understood that the House and Senate changed the representation on the Commission in order to appease the federal judges rather than for some other purpose. See Feidler Interview, supra note 80.

87. H.R. Doc. No. 93-137, at 95 (1973); see also KENNEDy, supra note 45, at 52 (observing that the $C B$ "elevated the stature and the prestige of the [bankruptcy] court and assimilated the procedures to the procedures of the federal district court"). 
hancement would occur through modification of appointment, tenure, and compensation. The $C B$ would have made bankruptcy judges subject to presidential appointment with the advice and consent of the Senate, increased their tenure from six to fifteen years, and increased their compensation. The other route to enhancement of status would occur through modification of the role of the bankruptcy judge, so that the judge would have fewer "administrative" and more "judicial" responsibilities - the theory being that administrative actions dissipated the cloud of impartiality that otherwise enhanced the prestige of the judge. In pursuit of these aims the CB would have reduced bankruptcy judges' administrative responsibilities, expanded their jurisdiction, and increased their remedial powers. 88

Judge Weinfeld - now on the Commission - rejected the Commission's argument in a separate statement and maintained that the existing system worked adequately, that bankruptcy judges' powers should not be changed, and that the appointment process should remain in the hands of the district judges, although perhaps tenure should be increased to twelve years. ${ }^{89} \mathrm{He}$ lost on all these issues. However, he and the other judge on the Commission, Hubert Will, prevailed on the other members of the Commission not to propose that the bankruptcy judgeship be made an Article III position. 90

Before identifying the sources of this conflict, let me mention the Commission's second major proposal regarding administrative reform. The Commission proposed the establishment of an entirely new independent agency in the executive branch, to be called "The United States Bankruptcy Administration." The Administrator would be a presidential appointee, with the advice and consent of the Senate, and would have a seven-year term. The Administration would take over the functions of the trustee and the administrative functions of the bankruptcy judge, and it would offer counseling services to debtors in consumer cases.91 Judge Weinfeld did not object to this proposal in his statement, but later, during the hearings, the federal judges and the bankruptcy judges would object to it.

Why did the majority of the Commission support the enhancement of the independence and prestige of the bankruptcy courts, while Judge Weinfeld opposed it? Why did the Commission sup-

88. See H.R. Doc. No. 93-137, at 85-96.

89. See id. at 299-301 (separate statement of Judge Edward Weinfeld).

90. See KENNEDY, supra note 45 , at 52.

91. See H.R. Doc. No. 93-137, at 117-53. 
port the creation of a bankruptcy agency while the bankruptcy judges opposed it? Looking beyond the parties' statements and at their interests, it appears that the proposed administrative structure refiected concerns about maintaining and expanding power, especially the power of patronage.

Seven of the nine members of the Commission came from the executive and legislative branches, both of which had an interest in creating new patronage opportunities. The bankruptcy courts described in the $C B$ would have served this interest by (1) transferring the appointment power from the judicial branch to the legislative and executive branches, and (2) making the position of bankruptcy judge more attractive to candidates and thus a more valuable currency for repaying political debts. The creation of a bankruptcy agency would have served the executive and legislative branches' interest in patronage opportunities by creating one advice-andconsent position and countless subsidiary positions, to be filled by political allies.

The federal judges opposed the creation of more independent bankruptcy courts, because (1) they would lose their appointment power over bankruptcy judges, and thus one of their main patronage opportunities, and (2) their status would be diluted through the vast increase in the number of federal judicial positions. The federal judges also opposed the creation of the bankruptcy agency, because to the extent that the agency would deprive bankruptcy judges of the power to appoint trustees and to the extent to which the bankruptcy judges were within the control of the federal judges, the creation of the bankruptcy agency would reduce the power and independence of the judiciary.

The bankruptcy judges supported the enhancement of the power and prestige of the bankruptcy courts, because they would gain power, status, and possibly pecuniary compensation. Bankruptcy judges had for a long time complained about what they saw as their low status, ${ }^{92}$ and they saw bankruptcy reform as an opportunity to solve this problem. Said one observer about the JB: "I

92. See 1977 House Supp. Hearings, supra note 58, at 227-28 (testimony of Attomey General Bell); 1975-76 House Hearings, supra note 54, at 539 (statement of Harold Marsh, Jr., Former Chairman, Commission of Bankruptcy Laws of the United States, claiming that bankruptcy judges "resent their status as being subordinated to and depende[nt] upon the Federal District Court"). Here is an example of the issues at stake:

We think that it is demeaning and unbecoming for a district judge to enact a local rule requiring that any fee in excess of a rather minimal amount, $\$ 200$, must be passed before the district judge for approval before it can be allowed, remembering that he has had nothing whatsoever to do with this case.

... If there is a major, serious contempt that involves something more and requiring something more than a fine of $\$ 200$, it has got to be transferred and certified to a district 
think the Judges' bill is the result of the fact that these are judges and they want to be judges and judges' judges and this accounts for what is in the Judges' bill, the need for status."93 Although the CB would not have enhanced the bankruptcy judges' status and power as much as the $\mathrm{JB}$ - in particular, the latter would have made appeal to the circuit court, bypassing the district court, in effect treating bankruptcy courts and district courts as equals ${ }^{94}$ - it did enough to garner the bankruptcy judges' support in this respect.

The bankruptcy judges, however, opposed the creation of the bankruptcy agency. One judge testified:

My view is that a national corporate trustee will be the framework for another huge bureaucracy with tentacles reaching into every area of the country and marked with all the weaknesses of inept officialism, expensive red tape and corruption inducing proliferation [sic]. This last consideration is vital for the temptation and the opportunity for corruption will be unlimited. 95

A more plausible explanation for the bankruptcy judges' opposition to the bankruptcy agency is that the latter would have deprived them of their main source of patronage - the power to appoint

judge. We feel that is totally inappropriate and tends to weaken the respect that litigants and lawyers should entertain for the bankruptcy court.

1975-76 House Hearings, supra note 54, at 153 (testimony of Bankruptcy Judge Robert B. Morton, President, National Conference of Bankruptcy Judges). Here is another:

While H.R. 31, the Commission Bill, strongly favors the elevation and independence of the new court there is one aspect of their proposal that is seriously flawed and, in fact, works against their own goal of enhancing the status and dignity of the new court. I refer to the H.R. 31 provision that clerks of the bankruptcy court be appointed from among the clerks of the district court with the concurrence of the district judges. That kind of hybridization would be as damaging as it is unnecessary and inconsistent. Any independent court worthy of the name must have a clear, unblurred line of authority to its own clerks.

Id. at 513 (statement of Bankruptcy Judge Robert B. Morton) (footnote omitted). Here is a third:

[T] he bankruptcy referees were certainly regarded at a different level from district judges [during the early post-World War II years]. In my early visits for meetings at Foley Square, the referees did not sit at tables with the district judges and, I believe, did not ride the same elevators. My recollection is that the referees didn't even have their names on their doors, but I'm not positive about that.

KENNEDY, supra note 45, at 32-33.

93. 1975-76 House Hearings, supra note 54, at 869 (testimony of Phillip Shuchman, Law Professor, University of Connecticut) (emphasis added).

94. The CB would have made the bankruptcy judge a presidential appointment, whereas the JB would have kept the appointment of the bankruptcy judge within the judicial branch. The CB's provision thus would have given power to the executive branch and the Senate; the bankruptcy judges may have believed that they had more influence over judicial appointments, or else they were trying to mollify the federal judges. The JB also would have expanded some of the administrative powers placed within the judicial branch. See 1975-76 House Hearings, supra note 54, at app.

95. H.R. Doc. No. 93-137, at 112 (quoting Bankruptcy Judge Asa S. Herzog); see also Levin \& Klee, supra note 28 , at 3. 
trustees from their acquaintances in the local bankruptcy bar. ${ }^{96}$ As a bankruptcy judge (and his clerk) wrote after the enactment of the bankruptcy bill, "Judicial appointment of a trustee is common, particularly in nominal asset cases filed by individual debtors. The court-appointed trustee is often understandably a personal friend of the judge who serves in a number of cases before that judge at a given time."97 The bonds of friendship are strong indeed.

If the patronage motives were half hidden in the Commission Report and related documents, they became clearer during the hearings in Stage 2. The federal judges, who had earlier resisted the bankruptcy judges' efforts to have their title changed from "referee" to "bankruptcy judge," apparently on the grounds that such a change would dilute the prestige of the title "judge,"98 reiterated their opposition to elevation of the bankruptcy judges and to the creation of a bankruptcy agency. ${ }^{99}$ Again, the federal judges could not admit that their motive was a fear of a loss of prestige, but a former judge made this rationale explicit:

[A] significant increase in the number of Article III judges, contemplated by [House Bill 8200], would dilute the significance, and prestige, of district judgeships. Prestige is a very important factor in

96. Such patronage - or at least its "appearance" - was widely acknowledged. See, e.g., 1977 Senate Hearings, supra note 72, at 1082 (statement of Margerie Girth, Law Professor, State University of New York at Buffalo, and David T. Stanley, consultant); H.R. REP. No. 95-595, at 92 (1977) ("Some judges view the trustee's job as a patronage position for the bankruptcy judge to dispense; the judge may even let it be known that elections are not viewed with favor."); 124 CoNG. REC. 32,419 (1978) (remarks of Rep. Butler).

97. John J. Galgay \& Kenneth H. Eckstein, Case Administration Under the Bankruptcy Reform Act: The United States Trustee Program, in ANNUAL SuRVEY of BanKRUPTCY Law 151, 152 (William J. Norton, Jr. ed., 1979) (footnote omitted).

98. This is generally known, but there is a reference to the controversy in 1977 House Supp. Hearings, supra note 58, at 192-93 (testimony of Judge David Kline, President, National Conference of Bankruptcy Judges).

99. See 1977 House Supp. Hearings, supra note 58, at 112-17 (statement of Judge Wesley E. Brown, Judicial Conference); $i d$. at 128-32 (statement of Judge Edward Weinfeld, Judicial Conference); $i d$ at 154-58 (response of Judge Wesley E. Brown to list of questions); 1975-76 House Hearings, supra note 54, at 5-6, 14-173 (statement and testimony of Berkeley Wright, Chief, Bankruptcy Division, Administrative Office of the U.S. Courts); id. at 20-21 (H. Kent Presson, Assistant Chief, Bankruptcy Division, Administrative Office of the U.S. Courts). The third document shows the judges seeking to keep the bankruptcy judges' powers and employment benefits below those of Article III district judges in every way: from a lower salary to denial of membership in the judicial conference. Cf. 1977 Senate Hearings, supra note 72, at 413 (testimony of Judge Ruggero J. Aldisert) (observing that all judges who considered this question (two circuits did not) unanimously opposed Article III status for bankruptcy courts: "I would like to emphasize ... that it is very unusual to get a group of [f]ederal judges to agree on anything. ... But I think it is very significant that ... there was unanimity in the Judicial Conference. . . ."). It is important to emphasize that Justice Burger was not acting on his own, as is sometimes claimed, but was acting on behalf of the entire federal judiciary. See Ruggero J. Aldisert, The Judicial Conference and the New Bankruptcy Act, 65 A.B.A. J. 229 (1979). 
attracting highly qualified men and women to the federal bench, from more lucrative pursuits.

....

... The benefits which might flow from increasing the prestige of that post [of bankruptcy judge] would be far outweighed by the dangers brought by a loss of prestige of federal district judgeships. ${ }^{100}$

In addition to the evidence that the judges feared losing status, there emerged evidence that they feared losing the patronage power to appoint bankruptcy judges. ${ }^{101}$ One must admit the possibility that the federal judges were right on policy grounds, but if they had been, one would have expected some support for their views from outside the judicial branch. Almost no one - creditors, debtors, or lawyers - expressed such support. ${ }^{102}$

Stage 2 also saw the bankruptcy judges reiterating their support for higher status bankruptcy courts and their opposition to the creation of a federal bankruptcy agency. ${ }^{103}$ Evidence of the bankruptcy judges' practice of appointing cronies to the position of trustee supports the hypothesis that the bankruptcy judges opposed the bankruptcy agency because they feared losing their patronage power. Some observers suggested the existence of a "bankruptcy ring," consisting of the local bankruptcy bar and bankruptcy judges who favored each other over outsiders. ${ }^{104}$ The bankruptcy judges de-

100. 1977 House Supp. Hearings, supra note 58, at 9 (statement of former (district) Judge Simon H. Rifkind).

101. Consider the following exchange:

Mr. McClory. One very good reason why district judges don't want to change the system, I think we must recognize, is that they enjoy appointing the referees, and they enjoy appointing special masters, too.

Judge Rifkind. Maybe they do.

1977 House Supp. Hearings, supra note 58, at 50; see also 1977 Senate Hearings, supra note 72, at 514-15 (testimony of Stanford Lerch, former Trustee). 117-21.

102. The major exception is the Attomey General. See infra text accompanying notes

103. See, e.g., 1975-76 House Hearings, supra note 54, at 512-16 (statement of Bankruptcy Judge Robert $B$. Morton).

104. According to one report:

As a result of the nature of the system itself, there exists a relationship between the Bankruptcy Judges, the trustees and the counsel for the trustees which many people, including many involved in the system, consider unhealthy from the point of view of proper judicial and governmental administration. The judges by and large appoint the trustees and thereby in effect select the counsel. They do not generally appoint persons who are total strangers to them, and it would be entirely unrealistic to expect that they would or should. These same trustees and lawyers then deal on a day-to-day basis with the judge regarding the routine conduct of the proceeding, and finally these same trustees and lawyers appear before the judge as litigants and counsel when a controversy arises.

As a result of the conditions discussed above, and I am sure for other reasons, there grew up over the years an isolation of the bankruptcy bench and bar from the mainstream of American jurisprudence and from the judiciary and the legal fratemity generally. Persons practicing in the bankruptcy field tended to confine their activities exclusively to that area, and the Bankruptcy Court, of course, did so from necessity. 
nied these allegations, arguing that defects in the system resulted from their lack of power, not from their abuse of it. They reiterated their view that their powers should be broadened, that an agency should not be created, and that they should continue to have the power to appoint trustees. ${ }^{105}$

The hypothesis that Congress saw an opportunity to increase its patronage powers by seizing appointment powers from the courts receives support from the following exchange between Representative Butler and Attorney General Bell regarding the question of who should appoint bankruptcy judges:

Mr. Butler. Selection by the President of the United States of bankruptcy judges? Would that disturb you? By the President?

General Bell. It would not. It would be a little different from what we're doing now, I guess - we're doing it the same way. We have a lot of these appointments.

As you know, I've been having a lot of problems with U.S. attorneys. That seems to be a big problem in selecting judges. I guess it's more political.

...

... You might be charged with giving the party in power more patronage. You have to recognize, if you have a system where the Judicial Council, or even the district judge recommending to the Judicial Council, that they be selected, you have less of a political system. Because some judges are Democrats, some are Republicans.

If you want to give it all to Democrats, we'd - we, being in power right now, I guess I couldn't object to it.

Mr. Butler. Patronage is a "burden" of power, I think, in my observation.

[Laughter.]

General Bell. It is a burden, I think. It really is that. I wouldn't quarrel with you if you think that's the way to do it. ${ }^{106}$

Bell's initial point was that appointments by the executive and legislative branches are seen as political, because all of the appointments are made by the party in power. Appointments by the judicial branch are not as controversial, because judges belong to

Therefore, a relatively small group of lawyers controlled the bankruptcy field. Those not within this group tended to regard them with suspicion and distrust.

1975-76 House Hearings, supra note 54, at 538 (statement of Harold Marsh, Jr., former chairman of the Bankruptcy Commission), reprinted in H.R. REP. No. 95-595, at 95-96 (1977); see also id. at 25 (testimony of $\mathrm{H}$. Kent Presson, Assistant Chief, Bankruptcy Division, Administrative Office of the U.S. Courts); H.R. REP. No. 95-595, at 95; KENNEDY, supra note 45, at 37 (describing the bankruptcy ring); Anne Colamosca, The Bankruptcy Hustle, THE NEw Republic, Feb. 17, 1979, at 15.

105. See 1975-76 House Hearings, supra note 54, at 587-88, 592-93 (statement and testimony of George M. Treister, Vice Chairman, National Bankruptcy Conference).

106. 1977 House Supp. Hearings, supra note 58, at 228-29 (testimony of Attorney General Griffin B. Bell). 
different parties. Bell apparently had disliked the political controversies that engulfed the Justice Department because of its role in the appointment of U.S. Attorneys, and, as we shall see, probably feared having to deal with similar controversies if the President were given the power to appoint bankruptcy judges because the Justice Department would have a role in those appointments as well. But he was forced to concede Butler's point which, though sarcastically made, must have been clear to everyone in the room (hence the laughter): the creation of opportunities for patronage benefits the party in power.

Lawyers, as noted, generally supported the creation of the higher status bankruptcy courts and opposed the creation of a bankruptcy agency, but they were divided in some respects. Commercial lawyers and bankruptcy lawyers strongly supported the creation of independent bankruptcy courts. ${ }^{107}$ One reason for their support was that in districts where the bankruptcy judge did not use the trustee position as a source of patronage, the bankruptcy lawyers used it as a source of profit:

Frequently, an attorney that has represented a creditor in past cases will notify him of the bankruptcy of one of the creditor's current debtors. The attorney then obtains a proxy from the creditor to vote the creditor's interest in the case. An attorney may obtain numerous proxies in a particular case in this manner. When the trustee is to be elected, the attorney votes all of his proxies for a colleague. The colleague thus elected then hires the attorney to serve as counsel to the trustee in the case, assuring a fee for th[ese] services. The fee for counsel is usually substantially higher than the fee for the trustee, because it is not limited to a specified percentage under the Bankruptcy Act. In a subsequent case, the colleague and the attorney will switch places. 108

By electing each other as the trustee and hiring each other as the trustee's counsel, bankruptcy lawyers assured themselves a steady source of business and a steady source of profit.

Another reason that commercial and bankruptcy lawyers supported the enhancement of the status of bankruptcy courts is that lawyers, like bankruptcy judges, care about prestige; just as it is more prestigious to argue in front of federal courts than to argue in front of state courts, so would it be more prestigious to argue in

107. See, e.g., id., at 77 (statement of Louis W. Levit, Chairman, Special Committee on the Bankruptcy Act, Commercial Law League of America); id. at 238 (National Bankruptcy Conference); 1975-76 House Hearings, supra note 54, at 1538.

108. H.R. REP. No. 95-595, at 92 (citing 1975-76 House Hearings, supra note 54, at 125253 (statement of John Honsberger, Canadian attorney) (discussing corrupt practices in Canada)). 
front of high-status bankruptcy courts than to argue in front of lowstatus bankruptcy courts. Shortly after World War II "bankruptcy lawyers were generally regarded as second-class members of the profession, they were not regarded with the same respect as civil lawyers."109 Frank Kennedy, the drafter of the CB, ingenuously describes how he and the National Bankruptcy Commission worked to enhance the stature of the bankruptcy bar by trying to effect changes in the law - for example, merging the bankruptcy rules and the federal rules of civil procedure in order to make civil cases in the district court and civil cases in the bankruptcy court as similar as possible. ${ }^{110}$ So deeply ingrained was their desire for respect, the bankruptcy lawyers did not see the enhancement of the prestige of the bankruptcy court as a controversial project, or that changing the law to that end might actually make the law worse.

Lawyers as a class were less enthusiastic about the proposed administrative changes but were generally supportive.111 They, like the federal judges, may have feared that an increase in the power of bankruptcy judges would lead to a general dilution of the status of the federal courts and thus a dilution of the status of lawyers practicing in federal courts. To the members of the American Bar Association this danger must have seemed minimal: they probably believed sensibly that an increase in the status of bankruptcy judges would not dilute the status of federal judges by much. But even so, this loss would hit hardest lawyers who specialized in nonbankruptcy trial work and who thus depended to an unusual degree on the status of the federal courts for their own status. These lawyers did oppose the creation of independent bankruptcy courts. ${ }^{112}$

Lawyers unanimously opposed the creation of a bankruptcy agency, particularly the proposal that it have the role of counseling consumer debtors. The lawyers argued that the agency would "destroy the private consumer bankruptcy bar" and create a "monopoly of lay counselors."113 The talk of "monopoly" is, of course, just

109. KENNEDY, supra note 45 , at 32.

110. See KENNEDY, supra note 45, at 33; see also id. at 55 ("[Because of the 1978 Act,] I think, generally, there has been an elevation or improvement of the status of the bankruptcy court and the status of bankruptcy law and bankruptcy administration. ... That's been my life-long objective, and I think it has been achieved in an important measure.").

111. The American Bar Association favored a longer transition period and more studies. See 1977 House Supp. Hearings, supra note 58, at 2 (statement of L. Stanley Chauvin, Jr., Chairman, Task Force on Revision of Bankruptcy Laws, American Bar Association).

112. See id. at 8-10 (statement of Judge Simon H. Rifkind, American College of Trial Lawyers).

113. See 1975-76 House Hearings, supra note 54, at 1269, 1270 (testimony of George Ritner, California attomey). 
talk: the lay counselors would be government agents, not employees of a single private enterprise. The lawyers objected to the proposal to give the bankruptcy agency the role of counseling consumer debtors because that role threatened a source of business for the lawyers. In addition, the federalization of the trustee system would have reduced the ability of locally influential bankruptcy lawyers to use their connections to obtain the position of trustee or to get themselves hired by the trustee. Lawyers who frequently acted as trustees supported the elevation of the status of bankruptcy courts while opposing the establishment of a bankruptcy agency ${ }^{114}$ - in both cases consistently with their interests, narrowly understood.

The creditors generally supported increasing the independence of bankruptcy courts, just because they hoped that higher-status courts would attract better judges and that more powerful bankruptcy courts would be less vulnerable to reversal by higher courts and attendant delays. ${ }^{115}$ They opposed the creation of the bankruptcy agency, at least partly because they feared that such an agency would encourage consumers to enter bankruptcy. ${ }^{116}$

The Department of Justice opposed the creation of independent bankruptcy judges and a bankruptcy agency. Attorney General Bell argued that bankruptcy judges should remain adjuncts of the district court, and that, although an official trustee was a good idea, he or she should be placed in the judicial branch.117 Bell opposed a proposal that the trustees be placed in the Department of Justice rather than in a separate bankruptcy agency, arguing that if the trustees were in the Justice Department, this would create conflict of interest problems, because in many cases the Justice Department

114. See, e.g., 1977 Senate Hearings, supra note 72, at 495 (testimony of Irving Sulmeyer, Trustee).

115. See 1977 House Supp. Hearings, supra note 58, at 194-96 (statement of John W. Ingraham, Vice President, Citibank Corp., and member, Robert Morris Associates Task Force on Bankruptcy); id. at 208 (testimony of George Wade, attorney, Robert Morris Associates Task Force on Bankruptcy); id. at 237 (testimony of Attorney General Bell) ("I have been a bank lawyer off and on all my life, and I'll guarantee you that the bank would have more confidence with the district judge handling the bankruptcy cases than they would under the present system."); see also 1977 Senate Hearings, supra note 72, at 862 (statement of John Creedon, Executive Vice President, Metropolitan Life Insurance Co.).

116. See, e.g., 1975-76 House Hearings, supra note 54, at 1028-29 (testimony of Walter W. Vaughan, Vice President, American Security Bank, and Chairman, American Bankers Association and Consumer Bankers Association Task Force on Bankruptcy); id. at 1044-45 (statement of Walter Ray Phillips, Household Finance Corporation, and Associate Dean \& Law Professor, University of Georgia); id. at 1361 (statement of Alvin O. Wiese, Jr., Chairman, Subcommittee on Bankruptcy, National Consumer Finance Association).

117. See 1977 House Supp. Hearings, supra note 58, at 215-19 (statement of Attomey General Bell). 
would then both represent a creditor (the United States) and participate in the administration of the debtor's estate. ${ }^{118}$ Bell also argued that the existing bankruptcy system worked well, and that as long as bankruptcy judges were given sufficient resources, it was not necessary to confer more status on them. Both of Bell's arguments were reasonable, and possibly candid, ${ }^{119}$ but other statements he made suggest that the Justice Department, which already managed the President's appointment of federal judges, did not want the additional burden of managing the President's appointment of bankruptcy judges. ${ }^{120}$ This was the tenor of the passage quoted above, in which Bell lamented his involvement in political controversies over the appointment of U.S. Attorneys. ${ }^{121}$ If this conjecture is correct, he would probably not have wanted the additional burden of managing the trustee system, either. The Justice Department opposed the proposed changes most likely because it would have had to bear the administrative and political costs arising from its role in appointments while gaining no benefits or benefits of uncertain value.

The House Hearings led to a bill that greatly expanded the patronage powers of the executive and legislative branches of the federal government. House Bill 8200 endorsed the idea of the stronger bankruptcy courts, indeed in many respects going beyond the provisions of the JB and the CB. Most significant, House Bill 8200 would have created Article III bankruptcy judges, with life tenure. The House Report argued that it was necessary as a matter of policy to increase the power and status of bankruptcy judges, but this could not be done under Article III of the Constitution unless the judges were given life tenure. This argument was plausible but not decisive, given the state of constitutional theory at the time. ${ }^{122}$ The House Report rejected proposals to leave bankruptcy judges as adjuncts of the district court, and it rejected proposals to turn them into Article I judges. In addition, House Bill 8200 gave the bank-

118. See id. at 218-19.

119. It appears that the trustee system has not raised problems relating to conflict of interest, so Bell's argument may not have been a frank one, though we have the advantage of hindsight. Cf. Bankruptcy Judges, United States Trustees, and Family Farmer Bankruptcy Act of 1986, Pub. L. No. 99-554, 100 Stat. 3088 (codified as amended in scattered sections of 11 \& 28 U.S.C. (1994)); H.R. REP. No. 99-764, at 17-20 (1986); GENERAL Govt. DIV., U.S. Gen. Accounting OfFice, Pub. No. GAO/GGD-92-133, BankRuptcy Administration: Justification Lacking for Two Parallel Programs, at 15-16 (1992).

120. See 1977 Senate Hearings, supra note 72 , at 553 (agreeing that presidential appointment of bankruptcy judges would be a "substantial burden" for the Justice Department).

121. See supra text accompanying note 106.

122. See 1977 HouSE SUPP. REPORT, supra note 57; H.R. REP. No. 95-595, at 21-39 (1977). 
ruptcy judges broad jurisdictional and remedial powers and provided that appeal from a bankruptcy order would be to the circuit court. ${ }^{123}$ This last provision was particularly unattractive to the federal judges, because it seemed to put the bankruptcy courts on par with the district courts. House Bill 8200 also followed the Commission's recommendation and created a federal bankruptcy agency, but put the agency in the Department of Justice. The administrator would be an appointment of the Attorney General. ${ }^{124}$

Although Senate Bill 2266 gave bankruptcy judges new powers, duties, and privileges (including the right to appoint their own clerks), it did not go so far as the House bill. Senate Bill 2266 did not turn bankruptcy judges into Article III judges, but it did increase their terms from six to twelve years. The power to appoint bankruptcy judges was transferred from district courts to courts of appeal. Administrative functions remained in the judicial branch. No federal bankruptcy agency was to be created. ${ }^{125}$ The overall effect was to raise the independence and status of the bankruptcy judges slightly, but not by nearly as much as under House Bill 8200 , and to prevent the shift of patronage power from the judiciary to the legislative and executive branches and from the local level to the national level.

The hypothesis that the House's bill ${ }^{126}$ was motivated by concerns about patronage should be examined in greater detail. ${ }^{127}$ It

123. See H.R. REP. No. 95-595, at 21-52.

124. See id. at $99-115$.

125. See S. REP. No. 95-989, at 144-59 (1978).

126. It should be pointed out that the House was not itself unanimous on the status of bankruptcy courts. When H.R. 8200 reached the floor of the House, two representatives proposed an amendment demoting the bankruptcy judge from Article III judge back to adjunct to the district court and eliminating the bankruptcy agency. The amendment passed by a vote of 183 to 158. See Bankruptcy Revision Bill, 33 Cong. Q. Almanac 571, 571-72 (1977). A few months later, after various parliamentary maneuvers, further hearings, see 1977 House Supp. Hearings, supra note 58, and an additional report, see 1978 HousE RE. PORT, supra note 59, the amendment was defeated by a vote of 146 to 262 . Republicans voted 67-73; Democrats voted 79-189. See Congress Approves New Bankruptcy System, supra note 41 , at $179,8-\mathrm{H}$. The lack of unanimity among the Democrats, and especially the tendency of Southern Democrats to side with the Republicans (43 voted against, 40 for), suggest that ideology may have played some role. According to Klee, the original amendment was caused by Justice Burger's lobbying. See Klee Interview, supra note 82. On this point, see infra text accompanying notes 137-141.

127. Klee, Levin, and Feidler disagree with the patronage theory. Although Klee believes that federal judges and bankruptcy judges exercised patronage prior to the 1978 Act, see Kenneth N. Klee, The New Bankruptcy Act of 1978, 64 A.B.A. J. 1865, 1866 (1978), he thinks that the transfer of power to the executive and legislative branches of the federal government was motivated by the desire to break up the old patronage system and not by the desire to create a new one. See Klee Interview, supra note 82; see also Feidler Interview, supra note 80; Telephone Interview with Richard Levin, Former Associate Counsel to the House Judiciary Committee (Apr. 10, 1997) [hereinafter Levin Interview]. 
is, of course, possible that the House believed that increasing the prestige of bankruptcy judges served the public interest, or, more likely, federal judges did not have as much infiuence on House members as did all the interest groups - creditors, lawyers, bankruptcy judges - that supported the enhancement of the bankruptcy court's prestige. The patronage hypothesis, however, receives support from a recent article, which provides evidence that expansion of the federal judiciary is likely to occur only when the Presidency, the House, and the Senate are controlled by a single political party at the time that the authorizing legislation is passed, and the Presidency and the Senate are controlled by the same party when the nominations and confirmations occur. ${ }^{128}$ The authors argue that expansion of the federal judiciary occurs during political alignment because expansion offers the controlling party an opportunity to appoint judges who share its political views and to dilute the influence of the sitting judges who do not. ${ }^{129}$ Although this argument is a plausible explanation for the subject of the study - the appointment of Supreme Court justices and federal appellate judges - it is unlikely that Congress cares much about the political views of bankruptcy judges. An alternative hypothesis is that when political alignment exists, Congress creates new judicial positions in part because these new positions can be used for patronage. When House Bill 8200 reached the floor, the Democrats had captured the Presidency as well as the House and the Senate, so the conditions were ripe for judicial expansion. Indeed, in the same year that the 1978 Act was passed Congress also passed the Omnibus Judgeship Act of 1978, which created 35 federal appellate positions and 117 district court positions, considerably more than Congress had ever created before, and the first new positions since the last political alignment in the late 1960s.130 One commentator called the Omnibus Judge-

128. See John M. De Figueiredo \& Emerson H. Tiller, Congressional Control of the Courts: A Theoretical and Empirical Analysis of Expansion of the Federal Judiciary, 39 J.L. \& ECon. 435 (1996). The article shows that for Supreme Court justices and federal appellate judges, political alignment is a significant factor in the timing of expansions, and that both political alignment and caseload pressures are significant factors in the size of the expansions. Other variables - increasing caseloads, requests from within the judiciary, budgetary growth - are not correlated with the timing of judicial expansion at a statistically significant level.

129. See id.

130. See id. at $448-49$ tbl.3 (describing statistics for appellate courts). Statistics for district courts can be found in Analytical Servs. OfFice \& Statistics Div., Adminstrative OFFICE OF THE U.S. COURTS, HISTORY OF FEDERAL JUDGESHIPS 28-29 tbl.B (undated).

It is true that new bankruptcy positions were created in 1984, when government had become divided; so were appellate court positions. But this is just one counterexample: the authors claim statistically significant, not perfect, correlation. 
ship Act a transfer to the President of "the largest block of judicial patronage in the nation's history." 131

One might object that Congress did not so much create new bankruptcy court positions as improve old ones; but because existing bankruptcy judges had no right to reappointment after their terms expired, Congress would have the opportunity to exercise its new patronage power. The crucial points are that Congress shifted the appointment power to the executive and legislative branches, and it increased the desirability of the positions, making them more valuable as currency for paying off political debts. If constitutional considerations required Article III status for bankruptcy judges, as further hearings suggested, ${ }^{132}$ then so be it. Recall that the Commission members other than the judges sought to create Article III positions. ${ }^{133}$

A similar argument can be made about the bankruptcy agency. The agency would require appointments, and these appointments could be used for patronage purposes. Detailed reasons for putting the bankruptcy agency in the Department of Justice are not given in the House Report - there was only a vague reference to the similar functions of trustees and U.S. Attorneys. ${ }^{134}$ One possibility is that this proposal retains most of the patronage opportunities created by the Commission proposal, but the agency, buried in the Department of Justice rather than standing on its own, would not be quite as obviously an expansion of the executive branch. ${ }^{135}$ In fact, the drafters of the compromise legislation providing for the pilot program chose districts in states represented by influential senators on the Judiciary Committee precisely for the purpose of giving them a patronage interest in the new appointments, and thus a motive for supporting an expansion of the pilot program into a permanent program at a later date. ${ }^{136}$ We will see that the U.S. Trustee system would be used for patronage purposes almost immediately after its creation.

131. See Alan Berlow, Carter Gets Patronage Plum of 152 Judges, 36 CoNG. Q. WKLY. REP., at 2961, 2961 (1978).

132. See 1977 House Supp. Hearings, supra note 58.

133. A possible objection to the patronage theory is the transition provisions of the bills, which delayed appointment for several years. If Congress was eager to increase its patronage power, why did it delay its ability to exercise that power until a time at which the old political alignment might no longer exist? The answer is probably that it would have been impractical to fire all the bankruptcy judges and replace them immediately.

134. See H.R. REP. No. 95-595, at 100, 109-11 (1977).

135. See infra text accompanying notes 149-52.

136. See Levin Interview, supra note 127. 
But if these arguments were true, one would expect the Senate to have supported these proposals. After all, under the House bill the Senate retained advice and consent powers over the appointment of bankruptcy judges, and one would expect the Senate's patronage privileges with respect to federal judges would have extended to bankruptcy judges. One possible source of the Senate's resistance is that senators believed that they would have to share some of this patronage power with House members, and the value of patronage appointments to the federal bench - a power enjoyed by senators, not by representatives - would have diminished as a result of the dilution of the federal judiciary. 137 Another reason for the Senate's objections to House Bill 8200 may have been that the Senate feared a transfer of power from the states, from which senators draw their power, to the President. This is consistent with the view that the Senate tends to support the interests of smaller states, which have disproportionate power in the Senate, over the larger states, which have more power in the House and the Presidency. A third and related reason is that many senators were ideologically committed to states' rights and populism, both of which opposed further centralization of authority in the federal government. A fourth reason is that most federal judges have powerful connections in the Senate, but not in the House: these connections are indeed the source of their appointments. An old political debt may not be fully discharged by an appointment to the federal judiciary - that is the problem with a barter economy. A sense of obligation may thus linger. Justice Burger had powerful connections in the Senate - in particular, Strom Thurmond - but did not have such connections in the House. ${ }^{138}$ Moreover, the urban interest groups that had so much influence in the House creditors and lawyers, especially - had less influence in the Senate. So although the Senate supported some increase in the status of bankruptcy judges, it had many reasons for objecting to an increase large enough to injure their federal judiciary franchise; and the Sen-

137. Federal appellate and district judges are generally chosen by senators from states in the relevant circuit. See Congressional QuARTERLy, Guide to CoNGress 247-48 (4th ed. 1991). Historically, the President has traded his patronage power for legislative support. See id. at 248-66, 549-51; Ronald N. Johnson \& Gary D. Libecap, The Federal Civil SERVICE SYSTEM AND THE PROBLEM OF BUREAUCRACy 16 (1994).

138. See Levin Interview, supra note 127. Participants in the drafting emphasize the importance of the ideological commitments of senators who held crucial positions (Wallop, Eastland), see Feidler Interview, supra note 80; Klee Interview, supra note 82; but these explanations have limited explanatory value. If these senators opposed federal power to such an extent that they resisted the creation of Article III bankruptcy judges, why did they at the same time permit the creation of a huge number of traditional Article III judgeships? 
ate opposed the creation of a bankruptcy agency, because this proposal would have transferred a great deal of local power to the federal government.

But given that expansion of patronage served the interests of Democrats in both chambers, it is no surprise that a compromise was hammered out. The bankruptcy judges would acquire significant new powers and independence, but they would become Article I judges rather than Article III judges. They would become presidential appointments, but their terms were limited to fourteen years, and appeal from their orders would be to district courts. Constitutional concerns ${ }^{139}$ were met with assurances from the Chief Justice that the Supreme Court would uphold the new bankruptcy positions. ${ }^{140}$ The bankruptcy agency would be put on a hold, but a pilot program would be initiated. The Democratic Party as a whole would benefit from the elevation of the status of bankruptcy judges, and because the party controlled the Senate, the Senate Democrats could be expected to consent as long as suitably compensated for any political disadvantage.

But one problem remained. The compromise may have satisfied the Senate Democrats' fear that they would lose patronage power vis-à-vis the House Democrats. It did not, however, address the federal judges' own desire not to lose any status at all. Hence, the dramatic intervention of Chief Justice Burger. Burger, who had earlier opposed the elevation of bankruptcy judges in a letter to Senator DeConcini ${ }^{141}$ and through the Administrative Office of the United States Courts, telephoned DeConcini and other senators, after the House passed the compromise bill, and complained about presidential appointment of bankruptcy judges, their retirement benefits, and their status as adjuncts to the circuit courts. ${ }^{142}$ "Burger 'not only lobbied, but pressured and attempted to be intimidating,' DeConcini said. He said the Chief Justice was 'very, very irate and rude." "143 Nevertheless, the second Senate amendment threw some crumbs to Burger in the form of remarkably petty reductions

139. See 1977 House Supp. Hearings, supra note 58; 1977 House SUPP. REPORT, supra note 57.

140. Or so it was believed by many representatives, who would later blame Burger for violating a deal when the Supreme Court struck down the bankruptcy positions in 1982. See Klee Interview, supra note 82 . It is possible that the representatives read what they desired into ambiguous statements. See Feidler Interview, supra note 80.

141. See 1977 Senate Hearings, supra note 72, at 878-79 (letter from Chief Justice Warren Burger to Senator DeConcini (Nov. 7, 1977)).

142. See Linda Greenhouse, Lobbying By Burger Provokes Criticism, N.Y. Times, Nov. 19, 1978, at 39; Congress Approves New Bankruptcy System, supra note 41, at 180.

143. Congress Approves New Bankruptcy System, supra note 41, at 180. 
in the independence and status of the bankruptcy judges. ${ }^{144}$ First, the Senate made it more difficult for bankruptcy judges to acquire clerks, adding a requirement that acquisition be "based on need" rather than based on right. ${ }^{145}$ Second, the Senate added to the appointment provision the requirement that the "President shall give due consideration to the recommended nominees of the Judicial Council of the Circuit within which an appointment is to be made."146 Third, the Senate eliminated the retirement plan of future bankruptcy judges and reduced the retirement benefits enjoyed by incumbents. Fourth, the Senate gave the chief judge of each circuit the power to evaluate the qualifications of incumbent bankruptcy judges who were to continue in the office during the transition. Finally, there is even an ambiguous provision that led Congressman Edwards to raise, but then dismiss, the possibility that the Senate sought to prevent incumbent bankruptcy judges from referring to themselves as "judges," rather than referees.147

Why did DeConcini make these concessions to Burger? There are two possible explanations. First, the vehemence of the federal judges' protest may have led DeConcini to reconsider his judgment that under the compromise bill the Senate would not lose too much patronage power. If federal judges were upset about the bill, that must mean that they expected to lose a great deal of status. If that was so and the position of federal judge would therefore become less attractive, the Senate had lost more patronage power than it had first thought. Second, DeConcini may have worried that the Supreme Court would undo the legislative deal, either by interpreting the statute in a strict way or even by striking down the already constitutionally suspect provisions dealing with bankruptcy judges. The House, in going along with the Senate's unilateral amendment, may have shared this concern. As mentioned earlier, the legislative managers understood the constitutional complications raised by the

144. That these concessions were directly in response to Burger's concerns and not motivated by something else is likely, as there is no evidence of any other intervening events. Senator Thurmond "said that the final version approved by the Senate incorporated a number of changes urged by Burger." Mike Shahan, N.Y. Thmes NEWSWIRE, Oct. 7, 1978, at 32; see also Robert Feidler \& Harry Dixon, Reflections on the Legislative History of the Bankruptcy Reform Act of 1978, in ANNUAL SURVEY OF BANKRUPTCY LAW 43, 51 (William L Norton, Jr. ed., 1979). Burger, not satisfied with these concessions, unsuccessfully lobbied President Carter to veto the bill. See Malcolm Wallop, Footnotes to the Bankruptcy Reform Act of 1978, in ANNUAL SuRVEY OF BANKRUPTCY LAW 53, 59 (William L Norton, Jr. ed., 1979).

145. See 124 Cong. Rec. 34,144 (1978) (speech of Hon. Don Edwards) (internal quotation marks omitted).

146. Id. (internal quotation marks omitted).

147. See id. 
proposed Article I status of the bankruptcy judges and doubtless feared that an offended Supreme Court could seize upon these complications and undo ten years of legislative work.

Before ending this story, we need to tie two loose ends. First, one might wonder why the Republicans went along with the Democrats' efforts to create patronage positions that only the Democrats would fill. The answer to this question is probably that resistance was futile given the Democrats' large majorities in each house; that little political gain could be achieved from resistance, because the subject was complex and the public uninterested; and that the Republicans may not have objected to the increase in federal patronage opportunities that would benefit them if and when they returned to political power. Note that when the House Democrats split over the question of elevating the status of bankruptcy judges and creating a bankruptcy agency, the Republicans sided with the dissenters - an indication that they opposed the increase in patronage that would benefit Democrats. ${ }^{148}$

Second, we noted earlier that the more sophisticated public choice models give some role to the electorate. Politicians do not make transfers to special interests when voters observe these transfers, disapprove of them, and respond to them by voting against the politicians when they run for reelection. One hypothesis is that politicians will choose an inefficient form of a transfer in order to conceal it from the voters. ${ }^{149}$ This hypothesis sheds light on some features of the legislative history of the Code. It seems likely that Congress modified the role of the bankruptcy judge in such a way that increased status, rather than simply increasing salary, because voters would more likely observe and object to the increase in salary. Thus did the 1977 House Report quote approvingly from a Justice Department report: "We will never pay the incomes to judges that they could earn in other pursuits and we must not create conditions that require us to settle for second best in the federal courts."150 The reason that judges cannot be paid their market value may be that voters do not want to spend that much on judges, or (more likely) judges' salaries are linked to Congressional salaries and voters do not want to spend too much on members of Con-

148. See Congress Approves New Bankruptcy System, supra note 41, at 179, 8-H.

149. See, e.g., Stephen Coate \& Stephen Morris, On the Form of Transfers to Special Interests, 103 J. POL. ECON. 1210 (1995).

150. H.R. REP. No. 95-595, at 22 (1977) (quoting COMMTTEE ON REVISION OF THE FED. Judicial SYs., U.S. Dept. OF Justice, THE NEEDS OF THE FEDERAL COURTS 7 (1977)). 
gress. ${ }^{151}$ In either case, payment in status is a disguised transfer, designed to circumvent the political restrictions on payment in money. In addition, we saw that the House decided to put the bankruptcy agency within the Justice Department rather than creating a new federal agency along the lines proposed by the Commission. In doing so, the House lost the opportunity to create a valuable presidential appointment; but it also reduced the likelihood of accusations of patronage. Voters and their watchdogs are more likely to object to the addition of a new agency to the federal bureaucracy than to some tinkering with the internal structure of an existing agency. ${ }^{152}$

Although our story ends in 1978, the reader may be interested in subsequent events. In 1982 the Supreme Court struck down the provisions in the 1978 Act relating to the position of bankruptcy judges. ${ }^{153}$ The Court held that the Act violated the Constitution by giving Article III powers to judges who do not have lifetime tenure and independent salaries. Justice Burger joined the dissent, which argued that the bankruptcy courts could be considered limited Article I courts. House members felt that Burger had broken a promise to deliver Supreme Court approval of the 1978 Act.154 Brennan, Marshall, and Blackmun, joined by Powell, formed the plurality. The outcome is probably attributable to their commitment to the independence of the federal judiciary, and not to the fact that much of the patronage power in the federal government had shifted to the Republicans in 1981. Rehnquist and O'Connor concurred on narrower grounds. Congress responded in 1984 by placing the bankruptcy judges more solidly under the authority of the district

151. In 1975 Congress linked salaries of members of Congress to those of other federal workers in an effort to disguise salary increases benefiting themselves. See R. Douglas Arnold, The Logic of Congressional Action 104 (1990).

152. There is a third question. How could it be the case both that bankruptcy judges expected to gain from the 1978 Act through reappointment and enhanced status, and that Congress expected to gain through increased patronage powers? If the judges kept their jobs, Congress would have been unable to have other people appointed. The answer is probably that the bankruptcy judges predicted (accurately) that they would be able to keep their jobs for a while, given the dislocation of transition, and that Congress saw the change as a relatively long-term change. In 1977 and 1978 future Republican power could not have been foreseen.

153. See Northern Pipeline Constr. Co. v. Marathon Pipe Line Co., 458 U.S. 50 (1982).

154. See Klee Interview, supra note 82 . This may explain why Burger insisted in a separate opinion that the plurality did not hold that the bankruptcy courts violated Article III and that the holding should be interpreted more narrowly. See Northern Pipeline, 458 U.S. at 92 (Burger, C.J., dissenting) ("I write separately to emphasize that, notwithstanding the plurality opinion, the Court does not hold today that Congress' broad grant of jurisdiction to the new bankruptcy courts is generally inconsistent with Art[icle] III of the Constitution."). 
courts. ${ }^{155}$ The way in which constitutional constraints interfered with attempts by the relevant political agents to strike a deal, one that gave bankruptcy judges more power but not too much more power, is worth some thought. They forced the participants either to keep the bankruptcy judges completely subordinate to the district courts or to make them Article III judges, as the House sought, and denied them an important route of compromise.

In 1986, the U.S. Trustee program was made permanent and expanded to cover every state, except Alabama and North Carolina. ${ }^{156}$ But in the meantime the patronage hypothesis - at least in outcome if not necessarily in intent - was confirmed. According to the first director of the Executive Office for U.S. Trustees, in the early 1980s "[t]he Department of Justice expressly said the [U.S. Trustee] program would get more support if politicians were invited to make U.S. Trustee appointments. They actually solicited various senators for their views as to who the U.S. Trustee should be."157 In doing so, the Justice Department merely followed the plan of the drafters. ${ }^{158}$ Similar, albeit not quite as credible, claims were made about the trustees appointed by the U.S. Trustees. One bankruptcy judge said:

When the pilot project started, I thought, "Maybe this is a good idea. Perhaps it will take some of the politics and favoritism out of the system," . . . I I quickly realized that it didn't. It just switched whose ox was being gored by whom. It was the U.S. Trustees' friends who were now being appointed as panel trustees. ${ }^{159}$

Aside from patronage concerns, there is a general view that the U.S. Trustee system has not worked well; this view will be discussed in the conclusion.

\section{EXEMPTIONS}

Federal and state interests divided even more sharply over exemption policy than they did over administrative structure. States

155. See Bankruptcy Amendments and Federal Judgeship Act of 1984, Pub. L. No. 98$353, \S \S 101$ (a), 104(a), 98 Stat. 333, 333, 336-41 (codified as amended at 28 U.S.C. $\S \S 151-58$, 1334 (1994)).

156. See Bankruptcy Judges, United States Trustees, and Family Farmer Bankruptcy Act of 1986, Pub. L. No. 99-554, 100 Stat. 3088 (codified as amended in scattered sections of 11 \& 28 U.S.C. (1994)).

157. How the U.S. Trustee Program Got Politicized, 29 Bankr. Ct. Dec. (CRR) A7, A7 (Oct. 22, 1996) (quoting Richard Levine, former Director, Executive Office for U.S. Trustees).

158. See supra text accompanying note 136.

159. Why Is the U.S. Trustee Program Such a Lightening Rod, 29 Bankr. Ct. Dec. (CRR) A1, A8 (Oct. 22, 1996) (quoting anonymous bankruptcy judge). 
had controlled exemption policy since the United States had come into existence. On the eve of the $1978 \mathrm{Act}$, federal bankruptcy law incorporated state exemptions, and although federal law supplemented state exemptions with a handful of federal exemptions (for foreign service workers, fishermen, seamen, longshoremen, railroad workers, and veterans ${ }^{160}$ ), the federal exemptions did not play a significant role in bankruptcy cases. The legislative history of the 1978 Act displays an effort by federal authorities once again to wrest control of exemption policy from the states.

To understand the conflict over exemption policy, one must distinguish the issue of federalism and the issue of the proper content of exemption law. The issue of federalism concerns whether the federal government or the states will have control over exemption policy. The issue of content concerns the proper level of generosity of exemption law, including both the monetary value of protected property and the kind of protected property. If politicians can gain political rewards by changing exemption law (in whichever direction), then one should expect a conflict between federal and local authorities over the power to control exemption law. If some interest groups have more power at the federal level while others have more power at the state level, then one should expect the former to prefer federal control of exemption policy and the latter to prefer state control of exemption policy. But whether control of exemption policy lies in the hands of state politicians or in the hands of federal politicians, interest groups will lobby the appropriate government for the exemption rules they prefer.

These observations raise the question whether the politicians involved in bankruptcy reform during the 1960s and 1970s actually believed that having control over exemption law was valuable. At first sight, one might think not. As noted earlier, many of the states' exemptions were archaic, providing protection for participants in an economy that no longer existed. Many states had not amended their exemption laws in dozens of years. If control of exemption law provided a fruitful means of making political payoffs, one might expect the kind of constant tinkering with it that one sees in tax law. The dominant view of commentators writing before the enactment of the Bankruptcy Code was that state legislatures did not care about exemption law. ${ }^{161}$

160. See S. REP. No. 95-989, at 75 (1978).

161. See, e.g., Countryman, supra note 30. 
This view, however, was wrong. Control over exemption policy had proved its value to state politicians in many ways. First, control over exemption law had allowed state authorities to respond to the demands of newly powerful classes of overburdened debtors during times of economic depression. Again and again during the nineteenth and twentieth centuries, states increased the generosity of exemption laws when an economic downturn caused default by debtors in large numbers. ${ }^{162}$ This legislation interfered with efforts by creditors to seize property to satisfy unpaid debts. The enactment of such laws must have been a straightforward and effective way for politicians to earn the gratitude of a large number of highly interested voters, the overburdened debtors, without alienating continuing debtors, who were probably sympathetic to the plight of overburdened debtors, and without risking much retaliation from the creditors, whose political power ebbed during economic downturns. Second, a glance at the current state exemption laws reveals the fingerprints of traditional interest groups. The exemption laws of virtually every state single out for favorable treatment groups of well-known political influence, such as insurance companies, farmers, teachers, veterans, and charitable organizations. ${ }^{163}$ Third, at least one state (Texas) and possibly others that sought to expand their population in the nineteenth century used exemption laws to encourage immigration from other states. By prohibiting creditors from collecting from the assets of residents, a state's generous exemption law encourages overburdened debtors to immigrate - a practice that continues to this day. ${ }^{164}$ Although it is true that many of the exemption laws on the books go back more than a hundred years, most states did modify their exemption laws from time to time, and they continue to do so even today. ${ }^{165}$

162. See Peter J. Coleman, Debtors and Creditors in America (1974); Charles WARREN, BANKRUPTCY IN UNITED States History (1935); Paul Goodman, The Emergence of the Homestead Exemption in the United States: Accommodation and Resistance to the Market Revolution, 1840-1880, 80 J. AM. Hist. 470 (1993).

163. Massachusetts, for example, singles out benefits from various insurance policies, see, e.g., MASS. GEN. LAWS ch. 175, $\S 110$ A (Supp. 1997) (accident and sickness insurance), farming products, see MAss. GEN. Laws ch. 235, $\$ 34$ (1975), pensions of public employees, see MAss. GeN. Laws ch. 32, $\$ 19$ (1993), veterans' benefits, see MASS. GEN. LAws ch. 115, $§ 5$ (1981), and fraternal benefit society benefits, see MAss. GEN. Laws ch. 176, § 22 (1958).

164. Cf. 1975-76 House Hearings, supra note 54, at 1369 (statement of Alvin O. Wiese, Jr., Chairman, Subcommittee on Bankruptcy, National Consumer Finance Association).

165. For example, Connecticut created a new $\$ 75,000$ homestead exemption in 1992 , see 1993 Conn. Acts 93-301, \$ 2 (Reg. Sess.) (codified as amended at ConN. GEN. STAT. ANN. $\S 52-352 b(t) \&$ note 10 (West Supp. 1997)); Califomia raised its homestead exemptions in $1990,1990 \mathrm{Cal}$. Stat. ch. 155, \& 1 (codified as amended at CAL. Civ. Proc. Code $\$ 704.730$ \& note (West Supp. 1997)), and created a $\$ 5000$ exemption for jewelry, heirlooms, and art in 1995, 1995 Cal. Stat. ch. 196, § 2 (codified as amended at CAL. Civ. Proc. Code $\$ 704.040$ 
If control over exemption policy was valuable to state politicians, then it must have appeared valuable to federal politicians as well. Control over exemption policy would have given federal authorities the power to provide relief to debtors in times of economic distress. More immediately, Congress would have the power to create exemptions that benefited insurance companies, banks, farmers, and other groups that could provide the greatest political support. To the extent that local control of exemption law created spillovers, control over exemption policy would allow the federal government to eliminate those spillovers and gain the support of those whom they injured. These considerations no doubt motivated the unsuccessful efforts of Congress to seize control of exemption policy in the nineteenth century and its successful efforts to create exemptions for particular categories of workers. And the same motivations would cause some members of Congress to use the widespread belief in the need for bankruptcy reform in the 1960s and 1970 s as an excuse for the federal government to seize control of exemption policy from the states yet again.

The normative case for federal control of exemption policy, however, was weak. The academic critics in the 1950s and 1960 s argued that Congress should enact a system of uniform federal exemptions on the grounds that the state exemptions were too often archaic, too variable, and too generous or too mean; ${ }^{166}$ but they never explained why control of exemption policy should lie with the federal government rather than with the states. ${ }^{167}$ The variability of exemption law suggested, if anything, that tastes about credit risk and protection against default differed greatly from locality to locality and that therefore uniformity imposed at the national level would have served no purpose.

The strongest case for uniform federal exemptions arises from the problem of spillovers. When states enact inconsistent laws, there sometimes results a "race to the bottom," in which all states become worse off as a result of their competition for resources. A common example is that of pollution: in the absence of federal pollution laws, states would enact suboptimal pollution laws because the cost of pollution is partly born by downwind or downstream

(West Supp. 1997)); Arizona raised its homestead exemption in 1989, see 1989 Ariz. Sess. Laws ch. 90, § 1 (codified as amended at ARrz. REv. STAT. ANN. § 33-1101 (West 1990)); and Washington modified its motor vehicle exemption in 1991, 1991 Wash. Laws ch. 11, \& 5 (codified as amended at WASH. REV. CODE $\$ 6.15 .010$ (1996)).

166. See, e.g., Countryman, supra note 30; Comment, supra note 30.

167. See Kennedy, supra note 30 , at $445-46,451-53$ (making this criticism). 
states, while the benefits of weak pollution laws, in the form of jobs and industry, accrue to the state that enacts the law. But if all states follow this logic, the aggregate costs will exceed the aggregate benefits. Uniform federal environmental laws would solve this prisoner's dilemma.

One analogy with respect to exemption laws concerns their effect on migration. As noted above, Texas originally created generous exemption laws to encourage migration from other states. Texas may correctly have calculated that the benefits of an increased population would exceed the higher cost of credit incurred by its citizens; but if all states had enacted generous exemption laws for this purpose, the migration gains would have disappeared while the cost of credit would have remained high everywhere. By preventing states from competing for migrants through exemptions, a uniform federal exemption law would prevent the race to the bottom. The problem with this argument, however, is that whatever the truth about Texas' motives in the nineteenth century, it is doubtful that modern states use exemption law to encourage migration, because people probably do not take exemption laws into account when deciding whether to migrate. 168

Another possible source of spillovers might be efforts by states to externalize the cost of default. If one state's exemption regime is more generous than those of other states, perhaps national creditors would spread the increased cost of collection in the highexemption state among debtors in all the other states. All debtors would pay the same higher interest rate, but debtors in the highexemption state would, in effect, pay less in interest charges for their right to keep more assets in case of default. But if the other states responded by increasing their exemptions, this benefit would be lost, while debtors in all states would pay the high interest rates - in effect, paying for more protection in case of default than they want. The problem with this argument, however, is that national creditors (to say nothing of local creditors) can adjust interest rates by state, charging the debtors in high-exemption states higher interest rates than they charge debtors in low-exemption states. ${ }^{169}$

168. Cf. Schill, supra note 11 , at $1295 \&$ n.173. One study finds a statistically significant correlation between the level of Chapter 7 filings in a state and the amount of immigration into that state, see Margaret F. Brinig \& F.H. Buckley, The Market for Deadbeats, $25 \mathrm{~J}$. LEGAL STUD. 201 (1996), but because most studies find no relation between the level of Chapter 7 filings in a state and the generosity of its exemption laws, see infra note 254 , the results of the study provide no reason for believing that generous exemption laws attract migrants.

169. Schill considers and rejects a similar spillover argument for state real estate exemption laws and related laws. See Schill, supra note 11 , at 1288-96. 
A third possible source of spillovers might be efforts by states to externalize the cost of poverty. Citizens in each state might believe that exemption laws should cushion people against bad luck or improvidence but fear that generous exemption laws would attract poor people from other states. Uniform exemptions would resolve this fear. The problem, again, is that no evidence suggests that generous exemption laws attract migrants in large numbers.

If spillovers caused significant losses, one would expect efforts by the states to produce a uniform law, because the reciprocity of the supposed harm means that uniformity would have produced mutual gains. ${ }^{170}$ Yet the uniform exemptions law recommended in 1976 by the National Conference of Commissioners on Uniform State Laws was enacted by just one state! ${ }^{171}$

Despite the shaky normative foundations for nationalizing exemption law, that idea made it onto the agenda of bankruptcy reform in the 1970s. The Commission endorsed the idea of uniform federal exemptions without justifying its position. It simply referred to the great diversity of state exemption laws. ${ }^{172}$ The particular exemptions contained in the CB - for example, $\$ 5,000$ homestead plus $\$ 500$ per dependent and $\$ 1,000$ for general personal property - were also not explained. In addition, the CB provided that the exemptions would be nonwaivable and gave the debtor the right to avoid judicial liens in exempt property and nonpurchase money security interests in household goods. The JB provided for a set of minimum federal exemptions - including $\$ 6,000$ plus $\$ 600$ per dependent for the homestead and $\$ 3,000$ for general personal property - and allowed the states to choose higher exemptions so long as they did not in the aggregate exceed $\$ 25,000.173$

It may seem facile to argue that the Commission favored uniform federal exemptions because they would transfer power over exemption policy from the states to the federal government. But recall that four of the nine members were members of Congress including Burdick and Edwards, the legislative managers for the Senate and House - and three were presidential appointees. ${ }^{174}$

170. Cf. Larry E. Ribstein \& Bruce H. Kobayashi, An Economic Analysis of Uniform States Laws, 25 J. LEGAL STUd. 131, 137-41 (1996).

171. See id. at 188-89 app. tbl.A1.

172. See H.R. Doc. No. 93-137, at 10, 170-73 (1973).

173. See 1975-76 House Hearings, supra note 54, at 146-47 app.

174. The only federal agency to testify on this topic, the Federal Trade Commission's Bureau of Consumer Protection, supported uniform minimum federal exemptions. See 197576 House Hearings, supra note 54, at 758-63 (statement of David H. Williams, Attomey, Bureau of Consumer Protection, Federal Trade Commission). 
The two federal judges on the Commission also probably had no objections - political or philosophical - to federal exemption law. ${ }^{175}$ The entire membership of the Commission comprised people whose position, influence, and interest were connected with the federal government; seven of the nine members either would directly benefit from a transfer of the power over exemption law from the states to the federal government or were appointed to the Commission by someone who would benefit from such a transfer. As agents of the federal government, they sought an expansion of its power. Against this, one might object that the Commission members simply did not realize that state authority over exemptions could be justified on normative grounds. They failed to provide a rationale for federal exemptions because the rationale was, in their minds, obvious. But this theory overlooks the fact that the reporter for the Commission, Frank Kennedy, had written an article defending the old law's incorporation of state exemptions just 13 years before the release of the Commission's report. ${ }^{176}$

Although bankruptcy judges were officials of the federal government, their power was local. Unlike the Commission members, they did not have an interest in transferring power over exemption law from the states to the federal government. Indeed, if they had any interest at all in the subject of exemption law, it was either to simplify it, in order to make their jobs easier, or not to change it, in order to avoid having to learn new law. The JB's endorsement of minimum federal exemptions may have been a compromise between these impulses. It may also have been designed to appeal to Congress, in order to give the bill legitimacy and plausibility. The $\$ 25,000$ ceiling is hard to explain; perhaps the bankruptcy judges thought that bankruptcy law would seem illegitimate if wealthy people could obtain protection from it. At any rate, this idea would have no influence on subsequent events. Because the bankruptcy judges did not share the Commission members' interest in federalizing exemption policy, they preferred to leave some of exemption policy under local control.

Rather than choosing between the $\mathrm{CB}$ and the $\mathrm{JB}$, House Bill 8200 established a set of federal exemptions but gave the debtor the right to choose between the federal exemptions and the state exemptions. This approach effectively meant that the federal exemp-

175. The Administrative Office of the U.S. Courts supported uniform federal exemptions. See, e.g., 1975-76 House Hearings, supra note 54, at 20 (statement of H. Kent Presson, Assistant Chief, Bankruptcy Division, Administrative Office of the U.S. Courts).

176. See Kennedy, supra note 30. 
tions provided a floor. These exemptions included $\$ 10,000$ for the homestead and $\$ 5,000$ for miscellaneous personal property. In addition, House Bill 8200 followed the CB in making the exemptions nonwaivable and giving the debtor the right to void a judicial lien in exempt property and a nonpurchase money security interest in household goods and related property. Senate Bill 2266 followed the 1898 Act and left exemption policy to the states. Although it added a right to redeem, it did not create rights to void any liens.

Why did the House retreat from uniformity and propose instead a federal floor? There is little evidence bearing on this question, but it is possible to make some conjectures. One conjecture is that state officials made their influence felt behind the scenes. Although state officials' first choice would have been to retain complete control over exemption policy, their influence may have been strong enough only to effect a compromise in which they retained control over the ceiling, the Congress over the floor.

Another conjecture emerges from the conflicting behavior of creditors. One might believe that creditors would, as a group, prefer a federal ceiling to a federal floor and that House Bill 8200 represented a defeat. In fact, the story is more complicated. The American Bankers Association supported minimum federal exemptions, ${ }^{177}$ while the National Consumer Finance Association and the National Credit Union Association favored uniform federal exemptions. ${ }^{178}$ Insurance companies ${ }^{179}$ and the National Association of Credit Management ${ }^{180}$ favored state control over exemption policy. To explain this distribution of positions, observe that creditor groups whose members were locally powerful - banks, insurance companies, and local businesses - preferred either complete state control or some state control. ${ }^{181}$ Creditor groups whose members

177. See 1975 Senate Hearings, supra note 71 , at 128, 136 (statement and testimony of Walter W. Vaughan, Vice President, American Security Bank, and Chairman, American Bankers Association and Consumers Bankers Association Task Forces on Bankruptcy).

178. See, e.g., 1975-76 House Hearings, supra note 54, at 1368-69 (statement of Alvin O. Wiese, Jr., Chairman, Subcommittee on Bankruptcy, National Consumer Finance Association).

179. See id. at 1584-85 (statement of John J. Creedon, Chairman, Subcommittee on Federal Bankruptcy Legislation, American Life Insurance Association); id. at 1645-49 (letter from National Association of Insurance Commissioners to Representative Don Edwards, Chairman, Subcommittee on Civil and Constitutional Rights).

180. See id. at 1674 (statement of Richard Kaufman, National Association of Credit Management). The National Association of Credit Management consists of manufacturers, distributors, financial institutions, and firms in service industries.

181. According to Klee, it was generally understood that banks had significant influence at the state level and used their influence on governors, who made their influence felt at the federal level through the National Association of Attorneys General. See Klee Interview, 
were not locally powerful - credit unions, finance companies ${ }^{182}$ preferred more federal control. Because their power was greater at the federal than at the local level, the credit unions and finance companies believed that their influence could ensure that only federal, not local, exemptions would be sufficiently low. Whatever the content of exemption law, creditors likely preferred authority over exemption policy at that level of government over which they had the most influence. ${ }^{183}$

Creditors may also have tried to use the opportunity of exemption reform to gain competitive advantages in the credit market. Banks issued lower risk credit, either secured or unsecured, and apparently, because of fear of bad publicity, usually avoided pursuing debtors too aggressively - for example, by taking household goods as collateral or seizing them from defaulting debtors. ${ }^{184}$ Consumer finance companies issued higher risk credit, both secured and unsecured, and did take household goods as collateral. ${ }^{185}$ If typical bank credit - especially, mortgage loans and loans secured by personal property - and finance company credit were close enough substitutes that an increase in the price of one would increase the demand for the other, then banks may have supported minimum federal exemptions in the hope that the higher effective exemption level that would result in states that had stingier exemptions would reduce the amount of collateral available to consumer finance companies without affecting the amount of collateral available to banks. ${ }^{186}$

This conjecture is supported by evidence of two related conflicts between banks and consumer finance companies. The first conflict

supra note 82. The political power of banks in many states is confirmed by research. See, e.g., Sarah McCally Morehouse, State Politics, Parties and Policy 108-12 (1981).

182. A list of interest groups that have power at the state level contains banks, business, and insurance companies, but not credit unions and finance companies. See MoreHouse, supra note 181, at 108-12 tbl.3-2.

183. Cf. Thomas R. Dye, Polmtics in States and Communtries 55 (3rd ed. 1977) (finding that oil companies preferred state regulation over offshore oil wells to federal regulation, because they feared having less influence over federal regulators than they already had over state regulators).

184. See Letsou, supra note 14 , at 632-33.

185. See id. According to the FTC, although banks sometimes rely on nonpurchase money security interests in household goods, "[f]inance companies are the preeminent users." Trade Regulation Rule, 49 Fed. Reg. 7739, 7762 (Federal Trade Commn. 1984) (credit practices) (commentary on 16 C.F.R. \$ 444).

186. A study of credit data from 1978 to 1983 found competition between bank automobile loans and finance company personal loans, bank personal loans and finance company personal loans, and bank mortgages and finance company personal loans. See Gregory E. Elliehausen \& John D. Wolken, Market Definition and Product Segmentation for Household Credit, 4 J. Fin. SERvices Res. 21 (1990). 
occurred over the right of redemption. Creditors generally dislike the right of redemption because it gives debtors the capacity to impose delay and litigation costs on the creditors, and debtors use the threat of delay to obtain some loan forgiveness. A limited right to redemption, however, would have a differential impact on creditors. Consider the right to redeem limited to goods, not real property, and excluding goods subject to purchase money security interests. This limited right to redeem injures the consumer finance companies, which depend heavily on nonpurchase money security interests in household goods; but it does not injure banks, because they depend mostly on real estate mortgages and purchase money security interests. The limited right to redeem thus might force the consumer finance companies to raise interest rates, driving their customers into the arms of the banks, whose interest rates would be unaffected. This may explain why in the legislative history banks supported a right to redemption of collateral except that used for purchase money security interests, ${ }^{187}$ while the consumer finance companies' opposed the right of redemption. ${ }^{188}$ The banks prevailed.

The second conflict occurred outside of the context of bankruptcy. When the FTC proposed rules restricting wage assignments and security interests in household goods, the consumer finance industry responded by challenging them through political and legal channels, whereas the banks remained mostly passive. An empirical study shows that legal restrictions on wage assignments reduced the amount of credit issued by consumer finance companies while not affecting the amount of credit issued by banks (and improving the position of credit unions). ${ }^{189}$ Although this study does not show that legal restrictions on security interests in household goods produced similar results, the logic is similar and so banks may have thought this result likely. The banks' passivity suggests that they saw in the proposed rules a competitive advantage. 190

Finally, insurance companies had done well at the state level. The exemption of insurance proceeds in many states encouraged

187. See 1975-76 House Hearings, supra note 54, at 1025, $1039-40$ (statement and testimony of Waiter W. Vaughan, Vice President, American Security Bank, and Chairman, American Bankers Association and Consumers Bankers Association Task Forces on Bankruptcy).

188. See id. at 1045-46 (statement of Walter Ray Phillips, Household Finance Corporation); 1977 Senate Hearings, supra note 72, at 651 (statement of Alvin O. Wiese, Jr., Chairman, Subcommittee on Bankruptcy, National Consumer Finance Association).

189. See Daniel J. Villegas, Regulation of Creditor Practices: An Evaluation of the FTC's Credit Practice Rule, 42 J. Econ. \& Bus. 51, 64, 65 tbl.3 (1990).

190. See Letsou, supra note 14 , at $634-35$. 
debtors who anticipated bankruptcy to sell off nonexempt property and purchase insurance. The insurance industry likely supported state control of exemption policy, because it did not want to risk losing its favorable position.

The national lawyer groups, such as the National Consumer Law Center ${ }^{191}$ and the Commercial Law League, supported federal control of exemption law, and their influence on Congress was greater than that of the local bar associations, which generally supported state control. Presumably, each group preferred seeing exemption policy in control of the level of government over which it had the most influence, but since it was Congress that was making the decision, the national groups did better than the local groups.

We can summarize the argument so far in the following way. Consider the biggest winners and losers from the federal exemption floor. In the stingy states the continuing debtors and creditors as a group would lose, but the lawyers, the overburdened debtors, and possibly certain powerful classes of creditors, such as the banks, would win. The losers had less political power at the national level than the winners did, especially because, as we saw, the creditors were divided by their interests. In the generous states a federal exemption floor would have had no effect.

Now consider the winners and losers from uniform federal exemptions. The story is the same for the stingy states, but in the generous states, now the lawyers, possibly the overburdened debtors, and certain creditors would lose, while the continuing debtors and creditors as a group would gain. In other words, the politically weak would prevail.

Minimum federal exemptions benefited some politically powerful groups without offending any other politically powerful groups, so they were preferred to uniform federal exemptions, which offended the politically powerful groups in the more generous states.

This argument raises the question why the Senate sought to leave exemption policy to the states. If the House would have gained from enacting a minimum exemption law because it would transfer payoffs from the state governments to the federal government, why wouldn't the Senate have gained as well? To answer this question, we must consider in more detail the relationship between local and national authorities.

191. The NCLC supported minimum federal exemptions. See 1975-76 House Hearings, supra note 54, at 937-38 (statement of Emest L. Sarason, Jr., Staff Attorney, National Consumer Law Center). 
We have been assuming so far that the federal government would seize political power from state governments whenever it could, but this assumption conflicts with observed behavior. In fact, there are two reasons why the federal government might leave certain areas of the law to the states, even though it has the constitutional power to legislate in these areas itself. ${ }^{192}$ First, when local interests have invested resources in understanding existing state legislation, they stand to lose their valuable legislation-specific expertise if Congress enacts superseding law. Recall that bankruptcy lawyers resisted the Chandler Act apparently because of the fear that it would eliminate the relevance of their expertise. ${ }^{193}$ To avoid this kind of loss, lawyers will pay off the federal government, either by giving support directly to federal politicians or by using their local influence to cause state politicians to pay off federal politicians.

It is true that bankruptcy lawyers and judges had valuable expertise regarding the nuances of state exemption law - the complexity of which cannot be exaggerated - and would have been reluctant to lose it. Indeed, the bankruptcy judges and many lawyers - and particularly local organizations, like state bar associations - opposed uniform federal exemptions and supported either state control or no more than a federal floor. ${ }^{194}$ Still, this story is not very satisfying. Exemption law composed a small portion of the bankruptcy lawyers' and judges' expertise, and with respect to other areas of bankruptcy law, far from opposing reform out of a desire to maintain the relevance of their expertise, they enthusiastically supported it.

The second reason why the federal government leaves legislative power with state governments is that state governments have

192. This is loosely based on Jonathan R. Macey, Federal Deference to Local Regulators and the Economic Theory of Regulation: Toward a Public-Choice Explanation of Federalism, 76 VA. L. Rev. 265 (1990). See also Robert P. Inman \& Daniel L. Rubinfeld, The Political Economy of Federalism, in Perspectives on Public Choice: A HaNdBook 73 (Dennis C. Mueller ed., 1997).

193. See supra note 34.

194. Local lawyers favored state control over exemptions, or federal minimum exemptions. The latter policy may have seemed attractive because it would allow them to use local influence to ratchet up exemptions without risking a reduction in the level of exemptions. Debtors' lawyers probably preferred high exemptions, because it increases the demand for their services; it is hard to say what creditors' lawyers would want. See, e.g., 1975-76 House Hearings, supra note 54, at 1256 (statement of Robert Ward, California bankruptcy attorney) (supporting state exemptions); id. at 1339 (statement of Paul L. Winkler, California bankruptcy attomey) (supporting federal minimum exemptions); $i d$. at 1558 (testimony of Louis W. Levit, Commercial Law League) (discussing support for federal uniform exemptions); id. at 1658 (statement of L.E. Creel, III, Dallas Bar Association) (supporting minimum federal exemptions). 
greater information about local interests than the federal government does and can therefore satisfy them more successfully; either the state governments or these local interests can take enough of the surplus from more efficient state regulation to be able to "pay" the federal government more than the latter would obtain through direct regulation. It is plausible that state politicians had quicker and more accurate access to information about the optimal level of exemption for the interests that benefited from it than did federal politicians. As a result, state officials had a greater ability to tailor exemption policy to the idiosyncracies of their state.195 In one state, for example, insurance companies are powerful and would pay a lot for exemptions for insurance proceeds; in another state, the farmers have all the power. If state officials could earn more political support from controlling exemption policy than federal officials could, then the parties had an incentive to make a deal in which the federal officials leave exemption control in state hands in return for some kind of "payment." The form of "payment" could, of course, vary. State officials might promise to supply patronage to federal officials or to support them in elections. In addition, interest groups with both local and national power could deter a federal takeover of exemption policy from the states by threatening to withhold support.

These stories suggest two reasons why the Senate and the House came into conflict over the level of government control of exemptions. First, senators owed more of their political power to state political organizations than representatives did. Exemption policy does not interest people at the district level; it does at the state level, since the state, not the district, is the source of state law. Second, the Senate was disproportionately influenced by the less populous, more rural states. ${ }^{196}$ The powerful farming lobbies in those states care deeply about a transfer of control over exemption policy from the states, where their influence is strong, to the federal government, where their influence is diluted. Since their influence at the federal level is stronger in the Senate than in the House, however, they can use their national influence to block the transfer.

Another reason for the difference may have been personal or ideological. Senator Wallop was a believer in state's rights and had recently been involved, as a state politician, in the amendment of

195. See id. at 864-65 (testimony of Philip Shuchman, Law Professor, University of Connecticut); id. at 762 (David H. Williams, Federal Trade Commission).

196. Cf. DYE, supra note 183, at 62 (observing that urban interests prefer national power to state power). 
Wyoming's exemption laws. As chairman of the Judiciary Committee, he had disproportionate control over the legislation, and apparently he cared only about this issue. Many senators had similar views about states' rights, whereas the House was dominated by believers in New Deal liberalism and centralized government. 197 It remains an open question, however, whether members cared enough about these ideological commitments to resist pressures from interest groups.

The compromise bill in Stage 3 provided still another variation on exemption law: a set of uniform federal exemptions, including the power to avoid certain liens, with a state right to opt out. The compromise meant that a state could, by legislative direction, force debtors to use exemptions that are lower than the federal exemptions; or it could force debtors to use exemptions that are higher than the federal exemptions; or it could leave the debtor the choice of using federal or state exemptions. The opt-out idea ingeniously gave the federal government control over exemption policy in all the states for which the interest in exemption policy was low, but not from the states that had a powerful interest in control of exemption policy. As a result, the federal government picked up some power without offending those with the most to lose. Most states did, in fact, opt out, showing again that the states did care about controlling exemption policy. Nevertheless, Congress gained some control over exemption policy.

There is one last question. Why was it never proposed that Congress create nonuniform exemptions - that is, exemptions that vary from state to state? After all, Congress had often enacted legislation that affected states differentially - for example, laws relating to building projects. Such a proposal would have allowed Congress to give each state the exemption law that maximized value to local interests and to gain in return the maximum amount of political support. The answer may be that Congress could obtain creditor support for federal exemption law only by promising to make exemption law uniform or at least more uniform than it had been. Creditors disliked the ability of debtors to change residences under the old law in order to escape collection. ${ }^{198}$ Another possible answer is that because one of the most powerful justifications for

197. This is Feidler's theory. See Feidler Interview, supra note 80.

198. See, e.g., 1975-76 House Hearings, supra note 54, at 1369 (statement of Alvin O. Wiese, Jr., Chairman, Subcommittee on Bankruptcy, National Consumer Finance Association); $i d$. at 1394 (statement of Jonathan J. Lindley, Director of Washington D.C. Office, Credit Union National Association). 
bankruptcy reform was the complexity of the old bankruptcy law, federal differential exemptions would have appeared to be a step backwards. A final answer, consistent with the theory presented above, is that determining the optimal exemption on a state-bystate basis would have been too complicated for Congress, and it did better by, in effect, franchising exemption policy to the states.

\section{BUSINESS REORganizations}

The legislative history of the Code contains a number of interesting conflicts over the law of corporate reorganization. It might surprise some people to learn that an argument that did not have much prominence is an argument currently used by many scholars to justify Chapter 11, namely that reorganization protects employees from the dislocation caused by economic and organizational transitions. A few parties raised this point in hearings in a desultory way, ${ }^{199}$ and the 1977 House Report mentioned it briefly, ${ }^{200}$ but it did not receive much attention or analysis, despite its populist appeal. 201

An important issue in the legislative history, by contrast, concerned the question whether the streamlined, pro-management procedures of Chapter XI should govern reorganization of large, publicly held corporations. Recall that between the late 1930s and the enactment of the Code in 1978, Chapter XI had become the preferred means of reorganization even for the public corporations for which Chapter X had been intended. Creditors supported the debtors' Chapter XI filings, and courts generally went along, resisting the SEC's efforts to convert to Chapter X. Managers preferred Chapter XI because Chapter XI left them in control of the firm during reorganization and gave them the exclusive right to propose the plan of reorganization. ${ }^{202}$ Chapter $X$ required the replacement of the managers with a trustee. Managers could use their Chapter XI powers to keep the firm alive while hoping for a change in market conditions. To be sure, managers did not necessarily ex-

199. See, e.g., 1977 Senate Hearings, supra note 72, at 623 (statement of Philip A. Loomis, Commissioner, Securities \& Exchange Commission).

200. See H.R. REP. No. 95-595, at 463-64 (1977).

201. Another interesting point is that unions foresaw that firms would have an incentive under the new law to declare bankruptcy in order to reject collective bargaining agreements. See 1975-76 House Hearings, supra note 54, at 2425-26 (statement of Max Zimny, General Counsel, International Ladies Garment Workers Union, AFL-CIO); id. at 2437-38 (statement of Jeffrey Gibbs, Counsel, Industrial Union Department, AFL-CIO). Their demands for restrictions on rejection for that purpose were ignored.

202. See id. at 1874-75 (statement of Harvey R. Miller, William J. Rochelle, Jr., and J. Ronald Trost, National Bankruptcy Conference). 
ercise their powers under Chapter XI. Studies of recent corporate bankruptcies show that managers rarely keep their positions after a firm enters bankruptcy, ${ }^{203}$ and this was likely the case prior to 1978. But managers probably could use their Chapter XI powers to extract concessions from the creditors, such as pecuniary compensation or an equity interest in the reorganized firm. ${ }^{204}$ Managers also probably liked Chapter XI's "best interests" standard, which guaranteed creditors only the liquidation value of their claims. If any going concern value remained, this could, in principle, be distributed to equityholders such as the managers. In contrast, Chapter $\mathrm{X}$ 's absolute priority rule distributed going concern value to interests with the highest priority.

The managers' preference for Chapter XI might lead one to believe that the creditors preferred Chapter X. Although creditors could buy off managers in a Chapter XI proceeding and have a receiver appointed who would be more sensitive to the creditors' interests, surely creditors would have preferred Chapter $\mathrm{X}$, because under Chapter $X$ they did not have to pay the management to resign and they were entitled to the going concern value of the firm.

There are several reasons why creditors - or, at least, some creditors - nonetheless preferred Chapter XI to Chapter X.205 First, Chapter $X$ proceedings always took a long time, whereas Chapter XI proceedings were usually brief. Chapter X required a large number of formal hearings and reports. Chapter XI proceedings were informal. Chapter $\mathrm{X}$ required that the SEC review the plan of reorganization - a process that took a long time - and it permitted it a thousand other interferences. One source of irritation was the SEC's position that equityholders with fraud claims had a right to rescission and refund of the purchase price, giving them priority over creditors. ${ }^{206}$ Creditors believed that the formal requirements of Chapter $\mathrm{X}$ and SEC participation produced delay, during which costs mounted and assets dwindled, without creating any offsetting benefits.

203. See Stuart C. Gilson, Management Turnover and Financial Distress, 25 J. Fin. EcoN. 241 (1989).

204. See Michelle J. White, The Corporate Bankruptcy Decision, J. Econ. PERsP., Spring 1989 , at 129 (discussing the issue of managers' incentives to choose to go into bankruptcy and to choose between liquidation and reorganization).

205. See 1975 Senate Hearings, supra note 71 , at $450-51$ (testimony of Richard Kaufman, National Association of Credit Management).

206. For a critique, see John J. Slain \& Homer Kripke, The Interface Between Securities Regulation and Bankruptcy - Allocating the Risk of Illegal Securities Issuance Between Securityholders and the Issuer's Creditors, 48 N.Y.U. L. REv. 261 (1973). 
Second, participating creditors had more influence in Chapter XI than they did in Chapter X. The creditors could elect their own receiver to operate the firm under the procedures of Chapter XI once they had obtained resignations from the managers - whereas they had to submit to the appointment of a trustee by the bankruptcy court under the procedures of Chapter X.207 In Chapter X the SEC challenged trustees who had connections with management, monitored their administration of the estate, and opposed any procedures and arrangements that did not meet its standard of fairness. ${ }^{208}$ Because the SEC and the bankruptcy court exercised greater supervision over Chapter $\mathrm{X}$ cases than over Chapter XI cases, participating creditors in Chapter $X$ had less influence over the outcome of reorganization than they did in Chapter XI.

Third, the practical distinction between the best interests standard and the fair and equitable standard was small. At first sight, one might think that creditors would prefer Chapter X, because the absolute priority rule gave creditors the going concern value of the firm; in Chapter XI the creditors were guaranteed only the liquidation value of the firm. When, however, a firm had no going concern value, which was often the case, the different standards led to the same outcome. When going concern value existed, the lower standard of Chapter XI did not injure the participating creditors, because it was only a floor and they could use their influence to negotiate a larger distribution. It could hurt only the nonparticipating creditors. Finally, the requirement that plans be "fair and equitable," under Case v. Los Angeles Lumber Products Co., ${ }^{209}$ could not be avoided by consent, and this of course meant that creditors could not pay off insiders in Chapter $X$ even when the latter could offer "new value." 210

These latter points are crucial. The procedural differences between Chapter X and Chapter XI had a significant effect on the ability of parties to engage in opportunistic behavior. Chapter XI favored those parties who participated in the reorganization namely, the managers and the large creditors. Shareholders and

207. Creditors lobbied for control of the trustee in reorganization cases. See, e.g., 1975 Senate Hearings, supra note 71, at 428 (statement of the National Association of Credit Management). A representative of another creditors' association stated that creditors preferred Chapter XI to Chapter X, because creditors had less say in Chapter X. See 1975-76 House Hearings, supra note 54, at 1685 (testimony of K. Richard Kaufman, Assistant Secretary, Credit Managers Association of Southem California).

208. See supra text accompanying notes 36-39.

209. 308 U.S. 106 (1939).

210. See Ayer, supra note 32, at 999-1001. 
small creditors - such as consumers, employees, and trade creditors - would generally not participate, because when one's claim is small the cost of participation exceeds the expected gains. ${ }^{211}$ Thus, in Chapter XI managers and large creditors could conspire to create a plan that transferred value to them from the small creditors and, if the firm was not insolvent, the nonmanagement shareholders. ${ }^{212}$ Chapter X favored the small creditors and the nonmanagement shareholders, because the court and the SEC would guard their interests. To be sure, large creditors could potentially do better in Chapter $\mathrm{X}$ because of the absolute priority rule, but it appears that they did better by paying off managers, and freezing out nonmanagement equity and small debt under the quick and informal procedures of Chapter $\mathrm{XI}^{213}$ than by sharing with small debt and possibly with equity and enduring delay under the cumbersome procedures of Chapter X.

This view receives support from the legislative history. The large creditors participated vigorously, arguing that the new bankruptcy law should follow Chapter XI, not Chapter X, and have informal, flexible procedures even for bankruptcies of large, public corporations. ${ }^{214}$ Small creditors were not organized, did not testify, and probably had little influence.

Besides the creditors, the most important groups to testify on reorganization were the lawyers' groups. Creditors' lawyers supported the Chapter XI-type procedures, probably in part because

211. For anecdotal evidence of the costs of serving on creditors' committees, see Why Creditors Don't Want To Serve on Creditors' Committees, 30 Bankr. Ct. Dec. (CRR) A1 (June 17, 1997).

212. A recent example in the news is the ability of top managers of bankrupt corporations to preserve their pension plans while the employees' pension plans lose their value. See Diana B. Henriques \& David Cay Johnston, Managers Staying Dry As Corporations Sink, N.Y. TIMEs, Oct. 14, 1996, at A1. Although the article is not entirely clear, it appears that some managers use their bargaining power to negotiate for pension protection during reorganization.

213. The existence of such behavior appears to underlie the SEC's objections to the CB and the JB. See 1975 Senate Hearings, supra note 71, at 762-64. It is also the theory of the court in Northern Pac. Ry. v. Boyd, 228 U.S. 482 (1913).

214. See 1975-76 House Hearings, supra note 54, at 1744 (prepared statement of Franklin Cole, Chairman of the Board, Walter Heller \& Co., Chicago, Ill.); id. at 1810-35 (comments submitted by National Commercial Finance Conference, Inc.; testimony of Eli Silberfield, General Counsel, National Commercial Finance Conference, Inc.; testimony of Carroll Moore, Chairman, Committee on Legislation; testimony of Leon S. Forman, Chairman, Committee on Preferences, Liens and Title, National Bankruptcy Conference). The bankers, while also strongly preferring the informal procedures of Chapter XI, would have allowed an exception for corporate reorganizations that would "materially and adversely affect" the rights of equity. See 1975 Senate Hearings, supra note 71 , at 648 (recording the recommendations of the American Life Insurance Association, whose members are major creditors of corporations); id. at 493, 498-99 (statement of Joseph Patchan, partner at Baker, Hostetler \& Patterson); id. at 1752 (statement of Robert J. Grimmig, American Bankers Association). 
their clients supported them. But the lawyers - particularly lawyers for corporate debtors - had an additional reason to prefer Chapter XI to Chapter X:

Unfortunately, by filing a chapter XI case not only does the debtor remain in possession, but the lawyer also remains in control. The lawyer can really control the progress of the proceedings. The lawyer has an awful lot to do with what happens in that chapter XI proceeding, and the lawyer for the debtor will be appointed the lawyer for the debtor in possession, and so he will remain, throughout, in a very active capacity in a chapter XI case. In a chapter X case that does not ordinarily follow. ${ }^{215}$

In Chapter X a trustee was appointed, and the lawyer would not earn a very large fee. So lucrative were the positions open to lawyers in reorganizations in Chapter XI that lawyers apparently engaged in misbehavior under the procedures of Chapter XI, particularly in their attempts to obtain control of creditors' committees. ${ }^{216}$

It is unclear whether Chapter X or Chapter XI better served the interests of shareholders, considered from an ex ante perspective. Chapter XI's "best interests" test gave them a better chance of obtaining some value from the reorganization than did Chapter X's requirement of a "fair and equitable" plan; but, as mentioned before, shareholders were unlikely to receive value under either test, since managers and creditors do not usually enter a solvent firm into bankruptcy. Shareholders may have feared, however, that managers would enter a solvent firm into bankruptcy in order to justify a capital restructuring that transferred wealth away from existing shareholders. If the speed of Chapter XI's procedures resulted in a lower cost of reorganization when reorganization was warranted, then shareholders would have preferred Chapter XI; but if the informality of Chapter XI's procedures enabled management to manipulate the process in its favor, then the shareholders could well have preferred Chapter X. That Chapter XI allowed management to have an interest in the reorganized entity was unlikely to benefit shareholders; as the SEC argued, there were more straightforward ways to pay for participation of management if such partic-

215. 1975 Senate Hearings, supra note 71, at 367 (testimony of Lawrence P. King, Associate Dean, New York University Law School, and consultant to the Bankruptcy Commission); see also 1975-76 House Hearings, supra note 54, at 1911 (testimony of William Rochelle, National Bankruptcy Conference); H.R. Doc. No. 93-137, at 247 (1973).

216. See 1975 Senate Hearings, supra note 71, at 444 (testimony of Larry Lawrence, National Association of Credit Management). 
ipation was necessary. 217 It seems likely that the optimal reorganization law for shareholders would have given less power to management than Chapter XI did - instead, giving power to an independent trustee, perhaps - while using less cumbersome procedures than those found under Chapter $X$. Whatever the case, shareholders did not have a sufficient stake to organize and played no role in the legislative history. ${ }^{218}$

As noted, managers would prefer Chapter XI procedures to Chapter $\mathrm{X}$ procedures, because the former allowed them to remain in control of the corporate debtor for a certain amount of time. Despite these benefits, managers did not testify. ${ }^{219}$ One possible reason is that managers do not generally believe that their firms will ever go bankrupt; another possibility is that testimony in favor of pro-management provisions in bankruptcy would have been bad public relations. ${ }^{220}$ The latter point suggests that managers might have exercised their influence behind the scenes. ${ }^{221}$ However, corporations have never been shy about lobbying state legislators for protection from takeovers despite the risk of bad public relations. ${ }^{222}$ Another possible reason is that the gain to managers from favorable reorganization law was just not that much relative to the cost of lobbying; in this sense, they may have been an unorganized and uninfluential group like the shareholders. But even if this were so, their interests and the interests of commercial bankruptcy lawyers converged, because the lawyers would want their clients - the managers - to find reorganization attractive so that they would enter reorganization as much as possible. The managers' interest in Chapter XI procedures for the reorganization of public corporations under the new bankruptcy law was thus reflected in the

217. See id. at 756 (prepared statement submitted by the Securities \& Exchange Commission).

218. The conventional wisdom is that shareholders have little political influence because they are not organized, and they are not organized because they have relatively little at stake. See, e.g., Jennifer Arlen \& Deborah M. Weiss, A Political Theory of Corporate Taxation, 105 YALE L.J. 325, 363-65 (1995). In the 1970s the law discouraged institutional investors from lobbying, and institutional investors had much less power than they do today. See Edward B. Rock, The Logic and (Uncertain) Significance of Institutional Shareholder Activism, 79 GeO. L.J. 445 (1991).

219. Adler argues that corporate managers would resist efforts to amend the Bankruptcy Code in a way that would make it more favorable to shareholders. See Adler, supra note 7, at 343-45. Cf. F.H. Buckley, The American Stay, 3 S. CAL. INIERDISC. L.J., 733 (1994) (discussing political influences on the stay); Skeel, supra note 24, at 495-503 (criticizing Adler).

220. See Klee Interview, supra note 82.

221. The Business Roundtable did apparently lobby behind the scenes. See Klee Interview, supra note 82.

222. See, e.g., Romano, supra note 5, at 122-26. 
behavior of the lawyers, who vigorously lobbied for such provisions. ${ }^{223}$

The cleavage between the approaches of Chapter $\mathrm{X}$ and Chapter XI persisted throughout the legislative history of the Bankruptcy Code, and at every stage participants testified in conformity with their interests, as described above. Most observers agreed that reorganization of small, closely-held corporations should follow the informal approach of Chapter XI, because such corporations do not suffer from the distortions caused by the separation of management and equity. The chief dispute concerned whether the approach used for close corporations should also govern large, public corporations. This dispute was often unhelpfully phrased as the question of whether Chapters X and XI should be consolidated into a single chapter or should remain separate, but the real issue - the power to be given to managers of public corporations - is clearly discernable. Most of those who sought consolidation believed that Chapter XI procedures should control in cases involving public corporations. Everyone who resisted consolidation believed that rigorous procedures like those in Chapter X should control in cases involving public corporations. The consolidation language was rhetorically powerful, because a plea for simplification of the law always has resonance, but it did not affect the substance of the debate. Some participants advocated consolidation of the chapters but wanted the law to treat public corporations differently from close corporations; so they advocated consolidation of Chapters X and XI but with an exception for public corporations in the (single) chapter that would result.

The CB is a product of the last strategy. The Commission proposed consolidating the two chapters but creating special provisions for public corporations, albeit in a rather obscure way. Instead of the absolute priority doctrine implied by Chapter X's requirement of a "fair and equitable" plan and instead of the liquidation standard implied by Chapter XI's "best interests" test, the CB created a "fairness test" which had, according to the Commission, the following characteristics. The absolute priority rule would continue to be applied, but it would be softened by allowing "another look after the facts are in" (whatever that means) and by allowing equity to

223. See 1975-76 House Hearings, supra note 54, at 1539-40 (statement of Louis W. Levit, Chairman, Special Committee of the Judiciary, Commercial Law League) (note rejection of proposal of automatic subordination of manager claims); id. at 1657 (statement of L.E. Creel, III, Dallas Bar Association); 1975 Senate Hearings, supra note 71, at 622 (statement of California Bar Association, Committee on Relations of Debtor and Creditor). 
obtain some value if its future contributions, especially in the form of management, were thought essential to a successful reorganization. In addition, the court would not make the valuation necessary for this test if a public corporation was not involved and the parties, after full disclosure, negotiated a settlement. ${ }^{224}$ The idea behind this odd evidentiary provision was that the protection of the absolute priority rule would drop away when everyone consented to a reorganization, but again only in the case of close corporations. The absolute priority rule with a new value exception would apply when public securities were involved. In addition, an independent trustee would be discretionary but presumptive for public corporations, and although the SEC's role would be eliminated, its functions would be performed by the bankruptcy agency. The Commission thus recognized the possibility of a greater conflict in public corporations between the interests of management, on the one hand, and creditors and shareholders, on the other, than in private corporations. This difference justified greater procedural protections for reorganization of public corporations than for reorganization of private corporations. Behind the rhetoric of consolidation, the two-track system prevailed. ${ }^{225}$

House Bill 8200 followed the CB in emphasizing the importance of consolidation and in providing for a modified absolute priority rule that allowed consenting senior creditors to give up some value to equity in return for cooperation. This idea is uncontroversial when applied to close corporations, where ownership and control are undivided, but its application to public corporations raised serious difficulties. The problem is that the modified absolute priority rule allows management of public corporations to extract value from creditors by threatening to delay reorganization and to extract value from small creditors by conspiring with large ones. Indeed, the Supreme Court had made this point repeatedly in its opinions on equity receiverships, ${ }^{226}$ and again when it rejected an argument that the "fair and equitable test" of Chapter X permitted senior

224. This, in any event, is the Commission's description of the rule. See H.R. Doc. No. 93-137, at 258 (1977). A glance at the rule itself $(\$ 7-310(d)(2)(B))$ does not disclose the basis of this description; the rule is too vague. See 1975-76 House Hearings, supra note 54, at 261 app.

225. The JB continued the separate tracks of the old law and appeared not to make many substantive changes. Because the bankruptcy judges did not feel strongly about this aspect of their bill, disclaiming their support for it at the first sign of opposition, see 1975-76 House Hearings, supra note 54, at 1184, I will ignore their views.

226. See Northern Pac. Ry. v. Boyd, 228 U.S. 482 (1913); Louisville Trust Co. v. Louisville, New Albany and Chicago Ry., 174 U.S. 674 (1899). 
creditors to transfer value to managers in return for cooperation.227 But House Bill 8200 did not, unlike the CB, provide the "evidentiary" restriction on reorganization of public corporations. House Bill 8200 did not differentiate public and private corporations at all. Moreover, House Bill 8200 further weakened the absolute priority rule by applying it to classes of creditors, rather than to every creditor, so a senior creditor would lose value to junior creditors if outvoted by other creditors in its class. House Bill 8200 also did not provide for an automatic trustee, and it denied standing to the SEC. In these ways, House Bill 8200's treatment of reorganization of public corporations followed the informal route of Chapter XI, even more so than did the $\mathrm{CB}$, and in contradiction to prior law.

Senate Bill 2266, which maintained separate rules for public and private corporations, differed crucially from House Bill 8200 by forbidding management and creditors of public corporations to agree to a reorganization that locks out the shareholders and small creditors. Senate Bill 2266 endorsed the absolute priority rule in all its rigor. In particular, Senate Bill 2266 would have made confirmation of the plan depend on the court's finding that objecting classes (including equity) received adequate value. Senate Bill 2266 also provided for the automatic appointment of trustees for bankruptcies of public corporations, for standing for the SEC as the representative of unorganized shareholders and bondholders, and for a larger judicial role in valuing the business and assuring that the plan is fair. Whereas the House argued that shareholders were more sophisticated than they were when the Chandler Act was passed and could protect themselves as long as sufficient disclosure is made, ${ }^{228}$ the Senate insisted that shareholders in public corporations had to be protected from attempts by managers and large creditors to freeze them out.229

What explains the House's and Senate's divergence over the formality of procedures for the reorganization of public corporations? One explanation draws on the observation that lawyers and large creditors supported informal procedures. The House's constituency consisted of the populous urban areas where large corporations, with many employees and vast financial resources, exercised their greatest influence. The corporations exercised their influence through their managers, and these managers had strong incentives to preserve their power, even at the expense of the share-

227. See Case v. Los Angeles Lumber Prods. Co., 308 U.S. 106 (1939).

228. The full explanation is confusing. See H.R. Rep. No. 95-595, at 222-24 (1977).

229. See S. REP. No. 95-989, at 9-10 (1978). 
holders they represented. When a firm enters bankruptcy, the managers would like to retain control as long as possible and to have as much leverage as possible with respect to the creditors. The reader will be reminded of the recent successful efforts of entrenched management to lobby state legislatures for takeover protection that benefited the management at the expense of the shareholders.230 If managers exercised influence behind the scenes, they would have more influence over the House than over the Senate.

Also in the populous urban areas were the powerful banks and other large creditors, which, expecting to have large enough claims to find it worthwhile to participate in reorganizations, preferred rules that maximized the influence of participants over proceedings; and the lawyers, who preferred the informal procedures of Chapter $\mathrm{XI}$, which maximized their business and their control over the proceedings. The Senate, by contrast, was disproportionately controlled by smaller, less populous states, where managers of big businesses, large creditors, and lawyers ${ }^{231}$ existed in smaller numbers and had less influence. ${ }^{232}$ Lacking influential constituents with a strong interest in management and big credit, senators may have been open to the influence of the SEC, 233 which supported stricter procedures and standards for reorganization of public corporations ${ }^{234}$ - probably to protect its turf but probably also to protect public investors. Another possible explanation is that senators believed that protection of shareholders and junior debtholders was in the public interest, 235 though this hardly explains why members of the House did not take a similar view. More plausible, given the disproportionate influence of rural states in the Senate, is that the Senate's position reflected the populist fear of the power of vast public corporations, the same fear that produced Chapter $\mathrm{X}$ forty years earlier.236

230. See Romano, supra note 5 at $120-42$.

231. That lawyers had more influence in the House than in the Senate is shown by their greater success in the House than in the Senate in obtaining provisions granting generous attorneys' fees in bankruptcy cases. The House prevailed on this issue in the final bill. See 124 CONG. REC. 33,994 (1978).

232. This is a simplification. In some small states a few large creditors have disproportionate influence; for example, Aetna in Connecticut. See Romano, supra note 5 at 122-39.

233. The SEC apparently had a powerful friend in Senator Roth. See Klee Interview, supra note 82.

234. See 1975 Senate Hearings, supra note 71, at 732-33, 754-56 (summary of recommendations and statement of Securities \& Exchange Commission).

235. See S. REP. No. 95-989, at 10 (1978).

236. See Skeel, supra note 24. 
The support for special protections in the case of public corporations was thus awfully thin, and it is not surprising that the Senate conceded almost completely to the House on these issues during the final negotiations. The final bill did not contain special distribution rules for public corporations, and it kept the House's watereddown absolute priority rule. Although the final language was not explicit on this issue, it appeared to contain the new value exception sought by the House. ${ }^{237}$ The face-saving concessions to the Senate were meager: most notable, permission for the SEC to appear in bankruptcy court but not to appeal adverse orders, the automatic appointment of an examiner for the bankruptcy of public corporations, and the prohibition on issuing nonvoting stock. 238 The examiner could perform an investigation and issue a report on the debtor, but it did not have the standing or the coercive powers of the trustee. The interests of large creditors, the lawyers, and managers had prevailed over those of the shareholders and the small creditors, a result consistent with what appears to have been the distribution of political power.

\section{Miscellaneous}

\section{A. Student Loans}

The Commission Report recommended that educational loans not be dischargeable in bankruptcy. ${ }^{239}$ The recommendation apparently grew out of a concern that the increasing frequency of such discharges would undermine the student loan system. During the House and Senate hearings banks and other creditors, academic institutions, bankruptcy lawyers, bankruptcy judges, and several members of Congress testified in support of dischargeability. ${ }^{240}$ No

237. On this, see Ayer, supra note 32. See also Bonner Mall Partnership v. U.S. Bancorp Mortgage Co. (In re Bonner Mall Partnership), 2 F.3d 899 (9th Cir. 1993). Norwest Bank Worthington v. Ahlers, 484 U.S. 197 (1988), left the issue open.

238. See 124 Cong. Rec. 34,003-09 (1978).

239. See H.R. Doc. No. 93-137, at 12 (1973).

240. See 1977 Senate Hearings, supra note 72, at 619 (supplemental statement of Commercial Law League); 1975-76 House Hearings, supra note 54, at 981 (statement of Bankruptcy Judge Clive W. Bare); id. at 1029 (testimony of Walter W. Vaughan, Vice President, American Security Bank, and Chairman, American Bankers Association and Consumers Bankers Association Task Forces on Bankruptcy); id. at 1127-30 (statement of Clarissa Gilbert, President, U.S. National Student Association); id. at 1301 (statement of Bankruptcy Judge Joe Lee); id. at 1339 (statement of Paul L. Winkler, bankruptcy attomey); id. at 1368 (statement of Alvin O. Wiese, Jr., National Consumer Finance Association); 1975 Senate Hearings, supra note 72, at 315, 329 (statement and testimony of Richard A. Hesse, National Consumer Law Center); H.R. REP. No. 95-595, at 132 (1977). But see 1975-76 House Hearings, supra note 54, at 1394 (statement of Credit Union Association) (opposing dischargeability); 1975 Senate Hearings, supra note 72, at 215-22 (statement of Sheldon Steinbach, American Council on Education). 
major interest groups opposed dischargeability, but several members of Congress testified in opposition to dischargeability. House Bill 8200 provided that educational loans would be dischargeable, as under the prior law. ${ }^{241}$ Senate Bill 2266 provided that educational loans would not be dischargeable within five years of maturity. The final bill reflected the Senate's version.

Academic institutions benefited from dischargeability, because it transferred the burden of paying tuition from students to the government, artificially inflating the demand for education. Creditors benefited, because they earned interest on the loans but incurred no risk, because the government guaranteed the loans. Lawyers benefited, because recent graduates' main liabilities consisted of their student loans, and they had to hire lawyers in order to have them discharged. The victim of the dischargeability rule was the diffuse and unorganized public. However, the abuse of the system and the cost and unfairness to the taxpayer were clear enough that politicians could score points with voters by taking a public stand against dischargeability. The apparently opportunistic failure to pay debts, at the taxpayer's expense, was doubtless more readily comprehended and condemned by the average voter than the esoteric details of corporate reorganization and judicial administration. This may explain the unusually frequent testimony of members of Congress during the hearings. By testifying (and, of course, voting) in favor of nondischargeability, they created a record that would help them during their next election. ${ }^{242}$ Members of Congress not directly influenced by constituents on this issue may also have feared the budgetary implications of the government's increasing liability for discharged student loans. ${ }^{243}$

\section{B. The Fraud Exception To Discharge}

The House and Senate agreed to retain the 1898 Act's exception to discharge for debts issued after debtors had filed false financial statements with creditors. As one might expect, creditors and their lawyers generally testified in favor of the exception; debtors' lawyers testified in opposition of the exception. ${ }^{244}$ The latter argued

241. See H.R. REP. No. 95-595, at 132-34.

242. See, e.g., 1975-76 House Hearings, supra note 54, at 1087-94 (Rep. John N. Erlenborn, Illinois); id. at 1098-1127 (Rep. Edwin D. Eshleman, Pennsylvania); 124 CoNG. REC. 1791-93 (Rep. Allen E. Ertel, Pennsylvania).

243. See generally H.R. REP. No. 95-595, at 536-38 (supplemental views of Rep. Ertel).

244. See, eg., 1975-76 House Hearings, supra note 54, at 970 (testimony of Bernard Shapiro, California attorney) (noting that the National Bankruptcy Conference opposes exception); id. at 897-902 (statement of Linn K. Twinem, attorney, Beneficial Finance System) 
that creditors abused the fraud exception in two ways. Some creditors would give consumer debtors highly complex financial forms to fill out in the hope that the complexity would lead to mistakes, the mistakes could be represented as intentional misrepresentation, and thus the debt would be made nondischargeable. Creditors would also threaten to sue debtors for fraud in the hope of extracting from them a reaffirmation of their debts. ${ }^{245}$ The Commission had taken these claims seriously and recommended that the exception be eliminated. ${ }^{246}$ However, Congress compromised between the interests by adding some fee-shifting provisions designed to compensate debtors who litigate false claims of fraud.

\section{Reaffirmation}

Under the 1898 Act a debtor could reaffirm any debts dischargeable in bankruptcy. Debtors' lawyers, the FTC, and many academics opposed the right to reaffirm, arguing that creditors obtained reaffirmations through bullying and deception, thus depriving the debtor of a fresh start. ${ }^{247}$ Creditors and creditors' lawyers supported reaffirmation, no doubt because it reduced their bankruptcy losses a great deal. But they also made the plausible argument that the debtors themselves benefited from the right to reaffirm, as it enabled them to acquire new credit and to retain valued collateral. ${ }^{248}$ No one has noticed that a prohibition on reaffirmation would discourage debtors from filing for bankruptcy: by reducing their ability to obtain credit after bankruptcy, such a prohibition would make bankruptcy less attractive. The final law permitted reaffirmation, but also required approval by the bankruptcy court and established a thirty-day cooling-off period during which the debtor could unilaterally rescind the reaffirmation.

(supporting exception); id. at 923-25 (statement of Benjamin L. Zelenko, creditors' lawyer) (supporting exception); $c f$. id. at 891-93 (testimony of Phillip Shuchman, Law Professor, University of Connecticut).

245. See H.R. REP. No. 95-595, at 130-31.

246. See H.R. Doc. No. 93-137, at 176 (1973).

247. See, e.g., 1975-76 House Hearings, supra note 54, at 943 (statement of Emest L. Sarason, Jr., National Consumer Law Center); id. at 762-63 (statement of David H. Williams, attomey, Bureau of Consumer Protection, Federal Trade Commission); id. at 873 (testimony of Philip Shuchman, Professor of Law, University of Connecticut).

248. See, e.g., id. at 902-03 (statement of Linn K. Twinem, attomey, Beneficial Finance System); id. at 1023 (statement of Walter W. Vaughan, Vice President, American Security Bank; and Chairman, American Bankers Association and Consumers Bankers Association Task Forces on Bankruptcy). 


\section{CONCLUSION}

The dominant academic view of the Bankruptcy Code is that it works well. This view is not hard to understand. The Bankruptcy Code is in many respects an elegant and sophisticated piece of legislation. The 1898 Act had become intolerably ambiguous and archaic, really quite horrible, and the 1978 Act swept away the years of doctrinal cobwebs and incrustations, replacing them with a lucid, simple, and apparently humane system for dealing with overburdened debtors and helpless corporations.

The academic view, however, makes a typical lawyerly mistake: it confuses improvement in doctrine with improvement in policy. That post-1978 doctrine is clearer and simpler than pre-1978 doctrine does not mean that it better serves the public interest. Indeed, measured by the standards set for itself by the 1973 Commission, the Bankruptcy Code must be considered a failure.

Recall that the Commission listed the following complaints with the old system: (1) the rapid increase in the rate of bankruptcy filings (208,329 filings in 1967); (2) administrative waste; (3) insufficient generosity for debtors and failure by creditors to collect in bankruptcy; (4) lack of uniformity in the treatment of debtors; and (5) negligence and abuse on the part of bankruptcy professionals. ${ }^{249}$ The 1978 Act has not solved these problems. First, as discussed in more detail below, since 1978 bankruptcy rates have skyrocketed to over one million per year. Second, the efficiency of the current bankruptcy system is doubtful. From July 1, 1990, to June 30, 1992, for example, the total cost of the 1.2 million consumer chapter 7 cases exceeded gross receipts in these cases by almost $\$ 100$ million and distributions to creditors by about $\$ 250$ million. ${ }^{250}$ Third, exemption laws are more generous today than they were before 1978, but the generosity of exemptions is mostly a matter of state law. There are no statistics on the extent to which creditors use the bankruptcy system rather than swallowing losses from unpaid loans. Fourth, because of the role of state exemption law in the Bankruptcy Code, debtors continue to be treated nonuniformly. Fifth, although anecdotal evidence suggests that negligence and abuse are

249. See supra text accompanying notes $46-50$.

250. See General Govt. Div., U.S. Gen. Accounting Office, Pub. No. GAO/GGD94-173, Bankruptcy Administration: CASE ReceIPTs PaId to Creditors aNd ProfesSIONALS, at 34 tbl.II.2 (1994). For consumer bankruptcies, gross receipts were $\$ 427.4$ million, creditor distributions were $\$ 273.6$ million, total costs were $\$ 521.3$ million - including bankruptcy court costs and trustee and debtor attomey compensation, but not apparently including creditors' lawyers. For business bankruptcies, gross receipts were $\$ 1.5$ billion, creditor distributions were $\$ 929$ million, and total costs were $\$ 461$ million. See id. 
less widespread today than prior to 1978 , the lack of systematic evidence of this behavior both now and then makes generalization hazardous.

Now, it is doubtful that the 1973 Commission's rather haphazard list of complaints about the old law should be the standard for evaluating the Bankruptcy Code, and the statistics should be read carefully. One might criticize a private company that spent almost twice as much money to collect from debtors than it received from them, but the Bankruptcy Code's goals are more complicated. The pertinent question is whether, supposing the goals are proper, some other system would achieve them more cheaply. The answer to this question would take us beyond the scope of this paper. A more modest approach to bankruptcy reform draws on this article's conclusions about the political history of the 1978 Act. We can use these conclusions to evaluate complaints recently directed at that law and ask about the nature and likelihood of reform.

Consumer bankruptcy filings and exemptions. Many commentators worry about the rapid growth of consumer bankruptcies since 1978. Recall that the 1973 Commission had mentioned as a reason for bankruptcy reform the growth of bankruptcy filings from 10,196 in 1946 to 208,329 in 1967.251 In 1996 bankruptcy filings exceeded 1 million. One can obtain a more accurate sense of the trend by observing that from 1920 to 1960 , between about 1 in 2000 and 1 in 4000 people filed for bankruptcy, with no clear trend up or down. There was an anomalous dip in the mid-1940s, probably as a result of post-war prosperity. From 1960 to 1978, there was a gradual upward trend in filings, from about 1 in 2000 , to about 1 in 1000 . From 1978 to 1996 , filings increased from 1 in 1000 to about 1 in 270.252 A recent study suggests that a considerably larger portion of the population, ranging from fifteen percent to twenty-three percent, would benefit financially from filing for bankruptcy, and even larger portions would benefit if individuals engaged in sophisticated prebankruptcy planning. 253 Although academics disagree about the extent to which the increase in filings reflect the influence of the

251. See H.R. Doc. No. 93-137, at 2.

252. These statistics are published every year. See, e.g., Judictal Conference of THE U.S., ANNUAL RePORT OF THE DIRECTOR OF THE ADMINISTRATIVE OFFICE OF THE UNITED STATES CoURTs 117-21 (1978). For a compilation of statistics, see Joseph Pomykala, The Division and Destruction of Value: An Economic Analysis of Bankruptcy Law, at app. E \& F (1997) (unpublished Ph.D. dissertation, University of Pennsylvania) (on file with author).

253. See Michelle J. White, Why Don't More Households File for Bankruptcy? (1996) (unpublished manuscript, on file with author). 
Bankruptcy Code, 254 it is clear that if the quantity of bankruptcy filings was a problem in the 1960s, the Code has not solved it.

One explanation for the increase in the filing rate is the rise in the generosity of state exemptions. There is, however, little evidence for this view. But even if the view were correct, Congress can do little about exemptions, as they are determined by state law. Although some creditors and commentators advocate uniform federal exemptions, it is no more likely that Congress can preempt state exemption laws today than it could in 1978. Indeed, given recent trends in the devolution of power from the federal government to the states, a system of uniform federal exemptions appears more unlikely now that it did in the 1970s. A further irony should be observed. Most of the states that opted out of the federal exemptions in 1979 and the early 1980s did so in order to force debtors to use stingier state exemptions; 255 but now many - possibly most of the opt-out states provide for exemptions that are more generous than federal exemptions. The National Bankruptcy Review Commission will recommend a system of uniform federal exemptions for some property and floors and ceilings on state exemptions with respect to other property. 256

Double appeals. Bankruptcy litigants must appeal adverse rulings to the district court, and from there to the circuit court and the Supreme Court. Commentators criticize this rule, seeing little reason to believe that bankruptcy disputes need three levels of appeal when ordinary civil disputes need only two. We have seen that this system is an artifact of the federal judiciary's attempt to maintain their prestige prior to 1978. The double appeal system was a concession to the federal judges, a symbol of the subordination of the bankruptcy court to the district court. Assuming that the federal judiciary no longer would exert political pressure on this issue (as

254. See William J. Boyes \& Roger L. Faith, Some Effects of the Bankruptcy Reform Act of 1978, 29 J.L. \& Econ. 139 (1986); Ian Domowitz \& Thomas L. Eovaldi, The Impact of the Bankruptcy Reform Act of 1978 on Consumer Bankruptcy, 36 J.L. \& EcoN. 803 (1993); Richard L. Peterson \& Kiyomi Aoki, Bankruptcy Filings Before and After Implementation of the Bankruptcy Reform Law, 36 J. EcoN. \& Bus. 95 (1984); Lawrence Shepard, Personal Failures and the Bankruptcy Reform Act of 1978, 27 J.L. \& EcoN. 419 (1984); Alden F. Shiers \& Daniel P. Williamson, Nonbusiness Bankruptcies and the Law: Some Empirical Results, $21 \mathrm{~J}$. Consumer Afr. 277 (1987); Michelle J. White, Personal Bankruptcy Under the 1978 Bankruptcy Code: An Economic Analysis, 63 IND. L.J. 1 (1987); F.H. Buckley \& Margaret F. Brinig, The Bankruptcy Puzzle (Jan. 24, 1996) (unpublished manuscript, on file with author). Reint Gropp et al., Personal Bankruptcy and Credit Supply and Demand, 62 Q.J. EcoN. 217 (1997), presents evidence that generous exemptions restrict credit to low-asset households and expand credit to high-asset households.

255. See Teresa A. Sulitvan et Al, As We Forgive Our Debtors 44 n.23 (1989).

256. See Commission Endorses Uniform Federal Exemptions Proposal, 30 Bankr. Ct. Dec. (CRR) Al1 (June 3, 1997). 
seems plausible), the system will probably be abolished, as it should be. The NBRC has voted to eliminate the double appeals system. ${ }^{257}$

Article III standing for bankruptcy courts. The NBRC will recommend that bankruptcy courts be given Article III status. ${ }^{258}$ It will be interesting to see whether the federal judiciary will raise objections again. Because the bankruptcy judiciary has become more respectable, the federal judiciary might see in its elevation less of a threat to its status than in 1978. Even if federal judges raise objections to the elevation of bankruptcy judges, jurisdictional confusion and other difficulties raised by the bankruptcy courts' awkward position in the judiciary may cause Congress to ignore such objections.

The U.S. Trustee System. In a recent survey of the members of the American Bankruptcy Institute, the U.S. Trustee System was most frequently listed in response to a question asking for the three most important problems in the bankruptcy system. ${ }^{259}$ Although the survey does not supply the reasons for the respondents' dissatisfaction, other sources suggest that bankruptcy lawyers think that the U.S. Trustees do not appoint trustees in a fair way, possibly engaging in cronyism; intervene in cases on the basis of their publicity, rather than on the basis of the merit of the intervention; object to reasonable legal practices; do not perform adequate supervision; issue inappropriate guidelines that do not take account of local variations in legal culture and practice; and have little influence over bankruptcy judges. ${ }^{260}$ Accusations (and admissions) of patronage in the system were mentioned earlier. Many of these problems can be traced to the centralization of an institution whose purpose is inherently local. The political history of the 1978 Act gives reason to doubt that the current system is desirable. It is possible that bankruptcy judges who hold office today would appoint trustees

257. See Why the Commission Supports Change in Appellate Structure, 29 Bankr. Ct. Dec. (CRR) A5 (Jan. 14, 1997).

258. See Commission Votes on Tough Issues, Picks Up Momentum, 6 Consumer Bankr. News (CRR) 6, 7 (Jan. 16, 1997).

259. See ABI Releases Final Results of Bankruptcy Survey Part 1: Overview/Business Reorganization Issues, 29 Bankr. Ct. Dec. (CRR) A3, A3 (Jan. 14, 1997).

260. See, e.g., Levin \& Klee, supra note 28, at 4-5; Why Is the U.S. Trustee Program Such a Lightening Rod?, 29 Bankr. Ct. Dec. (CRR) A1 (Oct. 22, 1996); see also Peter C. Alexander, A Proposal to Abolish the Office of the United States Trustee, 30 U. Mich. J.L. REF. 1 (1996); Linda J. Rusch, Unintended Consequences of Unthinking Tinkering: The 1994 Amendments and the Chapter 11 Process, 69 AM. BANkr. L.J. 349, 354 \& n.31 (1995) (citing cases in which courts criticize the U.S. Trustee's appointments). 
more honestly than the pre-1978 judges and than the current Trustees. ${ }^{261}$

The bankruptcy judge's administrative powers. Some commentators have argued that bankruptcy judges should have greater administrative powers than they do under the 1978 Act.262 Recall that the elimination of the bankruptcy judges' administrative powers under the 1898 Act may have been motivated by the desire to enhance their status. It was thought that because an administratively engaged judge would look like a participant, he or she would appear to take sides and not to have the dignified cloak of impartiality. Whether or not this is true, the political motivation behind the separation of administrative powers and the normative justification should be kept separate, and the legal distinction rethought.

The debtor-in-possession model and the absolute priority rule. Many commentators believe that managers have too much control over the corporate debtor during reorganization. ${ }^{263}$ Some object to the difficulty of replacing incompetent managers with trustees;264 others object to the exclusivity period. ${ }^{265}$ We saw that large creditors prefer to deal with managers rather than trustees, that lawyers also prefer to keep managers in control during reorganization, and that these groups made their influence felt during negotiations over the new bankruptcy law. Because the amount of authority given to managers during reorganization reflected the balance of political power and not necessarily the public interest, modification of the debtor-in-possession rules may be justified. A similar point can be made about the current version of the absolute priority rule: it more likely reflects the interests of the creditors and lawyers who lobbied Congress in the 1970s than the interest of the public.

Reaffirmation. There still exists a conflict between those who support and those who oppose the right to reaffirm debts. The 1978 Act's compromise - the cooling-off period and the requirement of judicial approval - appears to be routinely circumvented. Debtors reaffirm their debts outside the bankruptcy proceeding, and state courts enforce the reaffirmation when debtors breach the con-

261. See General Govt. Div., U.S. Gen. Accounting OfFice, supra note 119.

262. See, e.g., Steven W. Rhodes, Eight Statutory Causes of Delay and Expense in Chapter 11 Bankruptcy, 67 AM. BANKR. L.J. 287, 311-15 (1993).

263. See, e.g., Should Debtors Have to Prove a Trustee Is Not Needed?, 29 Bankr. Ct. Dec. (CRR) A3, A3 (Dec. 3, 1996).

264. See id.

265. See Give the Commission a Piece of Your Mind, 29 Bankr. Ct. Dec. (CRR) A1, A14 (Oct. 15, 1996). 
tract. $^{266}$ It is unsurprising that a last-minute political compromise would not take into account this difficulty of coordination in a federal system. If circumvention is in fact routine, the restrictions on reaffirmation should either be dropped or strengthened, depending on one's view about the value of reaffirmations.

* * * *

Some readers might take this political history of the 1978 Act as an indication of the futility of legislative reform. If politics determines legislative outcomes, what is the purpose of reform? But such pessimism is unjustified. The lessons of the analysis are concrete and practical. Because of the indeterminacy of the normative arguments for and against various kinds of bankruptcy reform, one must rely on experience and history. The experience of lawyers and courts tells us which parts of the law create practical difficulties. History tells us which parts of the law reflect political compromises rather than normative goals. Because the political forces that led to unsatisfactory compromises in 1978 have changed, there is hope that proper amendments can now be made. But it must also be acknowledged that reformers face a new set of political forces in 1997, and these forces will limit the extent to which improvement can be achieved.

266. See Commission and NCBJ Examine Consumer Bankruptcy Issues, 6 Consumer Bankr. News (CRR) 1, 7 (Nov. 21, 1996). 